\title{
Non-Coding RNAs and Reactive Oxygen Species-Symmetric Players of the Pathogenesis Associated with Bacterial and Viral Infections
}

\author{
Zaki Milhem ${ }^{1,2, \dagger}$, Paul Chiroi ${ }^{1,+}{ }^{,}$Andreea Nutu ${ }^{1}\left(\mathbb{D}\right.$, Maximilian Ilea ${ }^{3}$, Mihaela Lupse ${ }^{4,5}$, Oana Zanoaga ${ }^{1}$ \\ and Ioana Berindan-Neagoe ${ }^{1, *(\mathbb{D})}$
}

1 Research Center for Functional Genomics, Biomedicine and Translational Medicine, Iuliu Hatieganu University of Medicine and Pharmacy, 23 Marinescu Street, 400337 Cluj-Napoca, Romania; milhem.zaki@umfcluj.ro (Z.M.); chiroi.paul@umfcluj.ro (P.C.); nutu.andreea@umfcluj.ro (A.N.); oana.zanoaga@umfcluj.ro (O.Z.)

2 Psychiatric Clinical, Emergency County Hospital, 126 Decebal Street, 400205 Cluj-Napoca, Romania

3 Faculty of Dental Medicine, George Emil Palade University of Medicine, Pharmacy, Science and Technology of Targu Mures, 540139 Targu Mures, Romania; ilea.maximilian@stud15.umftgm.ro

4 Department of Infectious Diseases, Iuliu Hatieganu University of Medicine and Pharmacy, 400348 Cluj-Napoca, Romania; mihaela.lupse@yahoo.com

5 The University Hospital of Infectious Diseases, 23 Iuliu Moldovan Street, 400348 Cluj-Napoca, Romania

* Correspondence: ioana.neagoe@umfcluj.ro; Tel.: +40-743-111-800

+ These authors had equal contribution and should be considered as co-first authors.

check for updates

Citation: Milhem, Z.; Chiroi, P.; Nutu, A.; Ilea, M.; Lupse, M.; Zanoaga, O.; Berindan-Neagoe, I. Non-Coding RNAs and Reactive Oxygen Species-Symmetric Players of the Pathogenesis Associated with Bacterial and Viral Infections. Symmetry 2021, 13, 1307. https://doi. org/10.3390/sym13071307

Academic Editor: Miroslav Miletín

Received: 9 June 2021

Accepted: 15 July 2021

Published: 20 July 2021

Publisher's Note: MDPI stays neutral with regard to jurisdictional claims in published maps and institutional affiliations.

Copyright: (c) 2021 by the authors. Licensee MDPI, Basel, Switzerland. This article is an open access article distributed under the terms and conditions of the Creative Commons Attribution (CC BY) license (https:/ / creativecommons.org/licenses/by/ $4.0 /)$.
Abstract: Infections can be triggered by a wide range of pathogens. However, there are few strains of bacteria that cause illness, but some are quite life-threatening. Likewise, viral infections are responsible for many human diseases, usually characterized by high contagiousness. Hence, as bacterial and viral infections can both cause similar symptoms, it can be difficult to determine the exact cause of a specific infection, and this limitation is critical. However, recent scientific advances have geared us up with the proper tools required for better diagnoses. Recent discoveries have confirmed the involvement of non-coding RNAs (ncRNAs) in regulating the pathogenesis of certain bacterial or viral infections. Moreover, the presence of reactive oxygen species (ROS) is also known as a common infection trait that can be used to achieve a more complete description of such pathogendriven conditions. Thus, this opens further research opportunities, allowing scientists to explore infection-associated genetic patterns and develop better diagnosis and treatment methods. Therefore, the aim of this review is to summarize the current knowledge of the implication of ncRNAs and ROS in bacterial and viral infections, with great emphasis on their symmetry but, also, on their main differences.

Keywords: infections; bacterial; viral; ncRNAs; ROS; microbiology; infectious diseases; diagnosis

\section{Introduction}

Infectious diseases caused by bacterial and viral pathogens remain a major global health problem. Despite all of the recent advances in antibiotic and antiviral developments, unsolved antimicrobial resistances and the lack of broad-spectrum virus-targeting medications still impose many challenges upon both the medical and economical systems [1,2]. In the United States, about 2.8 million individuals get an antibiotic-resistant infection each year, while the annual estimation of healthcare-associated infections can reach beyond 720,000 cases [3-5]. Moreover, according to the World Health Organization, despite the efforts made toward developing better antibacterial drugs, none of the 43 antibiotics within the current clinical trials fully addresses the problem of antimicrobial resistance. Likewise, viral infections are also a frequent cause of illness in all age groups. However, children, elders, and those with a suppressed or deficient immune system usually have a much 
higher risk of developing a viral infection [6]. Moreover, while the climate changes and the geographical movements increase, the number of viral infections has risen as well. Therefore, the incidences of bacterial and viral infections have now become a critical, worldwide issue.

Community or hospital-acquired pneumonia accounts among the main causes of morbidity, mortality, and healthcare-associated costs. Nowadays, there is a wider spectrum of recognized causes of such conditions: bacterial infections, viral infections, or viral and bacterial coinfections. However, the epidemiology of respiratory infections has changed over the past decades, as $40 \%$ of patients develop a viral infection as the primary cause of an illness. Still, bacterial coinfections are described as being commonly associated with the influenza virus. Such bacterial strains include Staphylococcus aureus, Streptococcus pneumoniae, Haemophilus influenza, and Streptococcus pyogenes. Furthermore, beyond influenza, many other respiratory viruses are well-described as primary causes of pneumonia: respiratory syncytial virus, rhinoviruses, adenoviruses, human metapneumovirus, parainfluenza viruses, and finally, coronaviruses [7-10].

Starting in December 2019, another respiratory virus was added to the viral infection bookmarks as the novel SARS-CoV-2 virus infection, which reached pandemic proportions, causing a severe respiratory disease called COVID-19 that has affected beyond 162 million individuals, causing more than 3.3 million deaths (May 2021). Like other coronaviruses such as the Middle East Respiratory Syndrome (MERS) CoV and Severe Acute Respiratory Syndrome (SARS) CoV, the novel coronavirus was reported to spread via respiratory droplets and close contact from human to human, which made it highly infectious and dangerous [11].

The lack of specificity associated with the current methods for discriminating between bacterial and viral infections represents a global health threat, especially in diseases such as pneumonia, the leading cause of hospitalization, with approximately 120 million new cases and one million deaths worldwide each year [12]. Furthermore, both respiratory bacteria and viruses are usually collected from children with pneumonia, so rapidly and accurately identifying the infectious pathogens can guide the treatment management and facilitate the judicious use of antibiotics. Even if there is a growing availability of molecular techniques for pathogen detection, laboratory results are typically available long after the final treatment decisions are made. As a consequence, antibiotic resistance, due to excessive and oftentimes unnecessary use of antimicrobial drugs, is emerging at a disturbing rate, outpacing novel antibiotic developments and inevitably elevating healthcare-associated costs. Therefore, the need for specific and efficient methods to rapidly determine the exact type of an infection has become urgent. Therefore, the current repertoire of molecular biomarkers associated with bacterial and viral pathogenesis (Figure 1) is expected to be extended. 


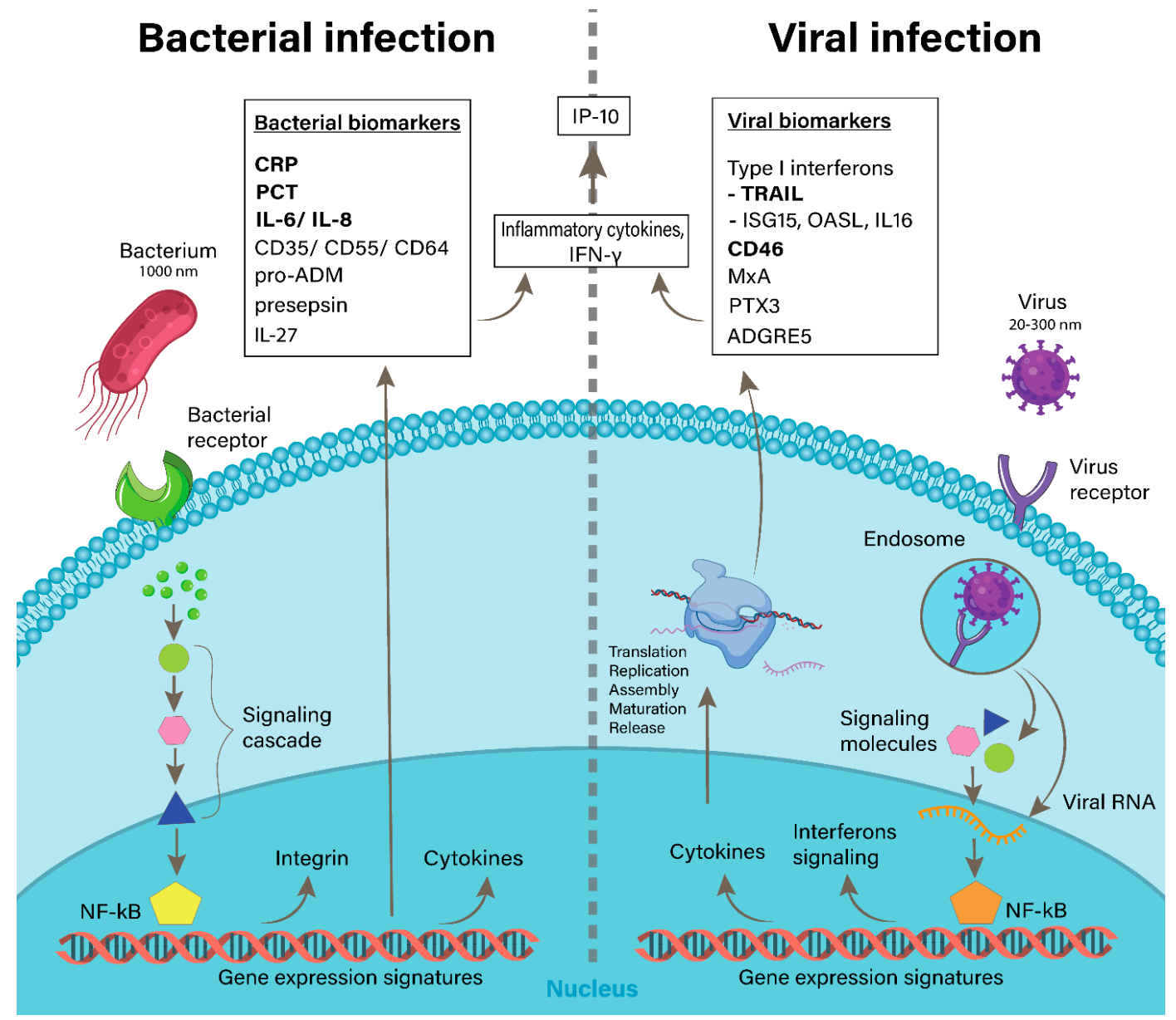

Figure 1. Comparative illustration between bacterial and viral infection pathogenesis. (Left) Bacterial infection pathways and their biomarkers that differentiate from viral ones. A differential diagnosis of bacterial infections is carried out using the relevant circulatory proteins, such as C-reactive proteins (CRP), interleukin-6 (IL6), and a biomarker-based biochemicalprocalcitonin (PCT) for bacterial infections. Some functions for CRP are recruiting a complement system, stimulating phagocytosis, and inducing an inflammatory response. (Right) Viral infection pathways in a cell and their biomarkers. Regarding gene expression signatures, viruses are more likely to trigger interferon (IFN)-related signatures, whereas bacteria are more likely to induce integrin-related signatures. The most significant performance in the cytokine infection biomarker family was interferon (IFN) such as type I interferon that relates to ISG15, OASL, IL16, and TRAIL. The last one is a member of the tumor necrosis factor (TNF) family, and it plays an important role in programmed cell death, such as the apoptosis of infected cells. (Middle) A proinflammatory chemokine secreted by immune cells, IP-10 is a biomarker for both types of infections. Abbreviations: CRP: C-reactive protein, PCT: procalcitonin, TRAIL: TNF-related apoptosis-inducing ligand, IP-10: interferon-gamma-induced protein-10, pro-ADM: pro-adrenomedullin, ISG15: Interferon Stimulated Gene 15, OASL: 2',5'-Oligoadenylate Synthetase Like, MxA: mycovirus resistance protein A, PTX3: Pentraxin 3, and ADGRE5: Adhesion G Protein-Coupled Receptor E5 [13-16].

Consequently, as the molecular level seems to be deprecated when it comes to diagnosing infectious diseases, the latest approaches tend to zoom in on the problem and focus on the genetic signature associated with those bacterial and viral pathogens. In this field, even if accounting for only $1.5 \%$ of the human genetic signature, the protein-coding exons remain the most studied sequences $[17,18]$. However, in recent years, the non-protein-coding portions of the genome have gained lots of interest, and the non-coding RNAs (ncRNAs) that were previously considered "junk RNA" are now emerging as key regulators of gene expressions in many physiological and pathological processes [19]. Ranging in size from 20 nucleotides in microRNAs (miRNAs) up to $>10,000$ in long non-coding RNAs (lncRNAs), ncRNAs are proven to take part in many different human disorders, including bacterial and viral infections [20-22]. Still, those two categories are just the tip of the iceberg, while 
there are many other types of ncRNAs identified so far: transcribed ultra-conserved regions (T-UCRs), small nucleolar RNAs (snoRNAs), PIWI-interacting RNAs (piRNAs), and large intergenic non-coding RNAs (lincRNAs) [17,23]. Nevertheless, ever since Warburg's 1908 observation of the increased oxygen consumption in fertilized sea urchin eggs that marked the first milestone in the ROS field, these oxygen species have been extensively studied within various scientific fields, including infectious diseases. Thus, while significantly contributing to regulating multiple physiological and pathological functions, ROS are also among the first signs of infectious diseases. Hence, their potential as valuable biomarkers for bacterial or viral infections started to be noticed [24]. Furthermore, ROS are known to play critical roles in immune defense mechanisms, including inflammation, against different pathogens, such as bacteria and viruses $[25,26]$. This trait could lead the way to innovative treatment strategies based on ROS and their immune implications in immune systems.

Most of the times, ncRNAs exist in clusters of 2-7 genes with small intervening sequences. Their biogenesis starts with post-or co-transcriptionally processing RNA II/III transcripts. About half of the currently identified miRNAs are intragenic and processed mostly from introns, while the remaining are intergenic, independently transcribed and regulated by self-promoters $[23,27]$. There are two distinct pathways when it comes to miRNA biogenesis. The canonical one that begins with the generation of pre-miRNA transcripts, which are further cleaved by the microprocessor complex Drosha and DiGeorge Syndrome Critical Region 8 (DGCR8) in order to obtain pre-miRNAs that will be further exported into the cytoplasm and mature into the mature miRNA duplexes. In the end, either its $5^{\prime}$ or $3^{\prime}$ strands will be loaded into the Argonaute (AGO) protein family to finally form miRNA-induced silencing complexes (miRISC). The noncanonical one starts with the cleavage of small hairpin RNAs (shRNA) that will be further exported via Exportin5/RanGTP (same as in the canonical pathway) into the cytoplasm to undergo AGO2-dependent and Dicer-independent cleavage. This noncanonical pathway will ultimately end with the formation of miRISC complexes [28].

Now, even if sometimes miRNAs and lncRNAs are more alike than they are different in term of biogenesis, there are also many differences within this process. Several DNA classes, such as enhancers or promoters, can be the starting point for IncRNA transcription, a process closely regulated by cell type-and stage type-specific stimuli. Most of the times, lncRNAs are transcribed by RNA polymerase II (Pol II), capped, polyadenylated, and further spliced during their transcription. However, sometimes, Pol II-transcribed lncRNAs are poorly processed and remain in the nucleus, but the remaining are usually spliced and ousted into the cytoplasm. If the lncRNAs contain one or only a few exons, their transfer into the cytoplasmic space is ensured by nuclear RNA export factor 1 (NXF1). In some cases, IncRNAs can be transcribed by a dysregulated Pol II, and as a consequence, they stick to the chromatin to be later degraded by the nuclear exosome. Other mechanisms involved in IncRNAs biogenesis are the development of mature ends by ribonuclease P cleavage, the establishment of small nucleolar RNA and protein complex caps, and the formation of circular structures. However, the processes associated with lncRNAs biogenesis and regulation are not yet fully understood, but one thing is for sure. miRNAs and lncRNAs do share a symmetry regarding their involvement in certain infectious diseases [29-31].

Hence, for their various implications in many different biological processes, ncRNAs have gathered more interest and started to be largely studied, up to the point where now we can confirm their involvement in mediating host-pathogen interactions and their associated immune responses [32]. There are numerous miRNAs that act alongside bacterial or viral pathogenesis or the host immune reaction, including miR-30, mi-R146, miR-128, miR-155, miR-15, miR-1289, miR-29, miR-K12-1, miR-K12-3, and others [33-35]. Although lncRNAs are not as conserved as miRNAs, they have an important contribution in regulating the gene expression, including the antiviral response [32]. Among the most important infection-associated lncRNAs to be found were: lncRNA-CD244, lncRHOXF1, lncRNA-CMPK2, IFNG-AS, and lnc-SGK1 [32,36-38]. 
Physiologically, cellular metabolism produces ROS as byproducts that are further involved in many biological processes, including cell signaling, hormone regulation, transcription, apoptosis, ion transport, and immunomodulation. Hence, they lend fundamental aid to the normal functioning of the immune system, especially regarding adaptive immune responses [39]. However, ROS are used by phagocytes and other cell types against different pathogens, and it seems that such defense mechanisms can occur directly through oxidative damage or indirectly by various nonoxidative mechanisms such as autophagy, pattern recognition receptors signaling, T-lymphocyte responses, and neutrophil extracellular trap formation. Still, there are certain pathogens in which ROS can also appear as infection promoters, including Mycobacterium tuberculosis, S. pneumoniae, Pseudomonas aeruginosa, Kaposi's sarcoma-associated herpesvirus (KSHV), human immunodeficiency virus (HIV), porcine circovirus type 2 (pcV2), etc. [40]. Therefore, ROS has proven to be an important involvement regarding many infectious diseases as well.

\section{Non-Coding RNAs in Bacterial and Viral Infections}

ncRNAs are known as a class of RNA molecules that do not code for proteins and which represent $98 \%$ of the human genome composition [41]. ncRNAs, including miRNAs, lncRNAs, and circular RNAs (circRNAs), are involved in the regulation of both physiological and pathological cellular processes. Hence, they play a key role in different human diseases through a variety of gene-regulation mechanisms [42] and in the modulation of the host defense system [43].

During infections, both the host and bacteria have two options: to either adapt to the changes of the environmental or physiological factors or react. The vast majority of bacteria can trigger the expression of so-called "virulence genes", which play a major part in disease pathogenesis, allowing the bacteria to benefit from the host resources. Likewise, infected organisms sense the intrusion and react by activating innate or adaptive immune responses. This complex interplay is referred to as host-pathogen crosstalk [44].

RNA is itself a key regulator molecule, as its physicochemical characteristics make ncRNAs versatile tools for interfering with gene expressions. Thus, a single ncRNA can regulate several pathways simultaneously, and one single gene can be modulated by various ncRNAs for efficient control in a broad range of conditions [44,45].

miRNAs are key regulators of the innate immune defense in response to lipopolysaccharides (bacteria membrane-associated components) [46]. This work has led to the characterization of miR-146 as an anti-inflammatory miRNA. Furthermore, miR-155, miR-146, let-7, and miR-29 also play important roles in the host cells' response to bacteria [47-49]. The contribution of lncRNAs in defense against viruses, especially in inflammatory responses to LPS and live bacteria, has shed more light upon the involvement of ncRNAs in the antiviral responses. Recently, lncRNA profiles in response to infections were analyzed in several mammalian cell lines, and their defense mechanisms were elucidated. Hence, ncRNAs have proven their involvement in the pathogenesis of bacterial and viral infections (Figure 2) [44].

Since ncRNAs have steadily emerged as key regulators of bacterial and viral infections, and novel genomic-based approaches have been developed, providing a more in-depth perspective of the interplay between certain pathogens and ncRNAs [50]. Finally, as one of the most powerful traits of ncRNA structures is to aim for multiple targets by precise base pairing, this allows cells to regulate gene expressions. The vast majority of miRNAs and lncRNAs are differentially regulated in response to bacterial or viral infections within various types of cell and tissues. Therefore, ncRNAs are considered a reservoir of gene expressions that can fine-tune an impressive repertoire of genetic targets (Table 1). 


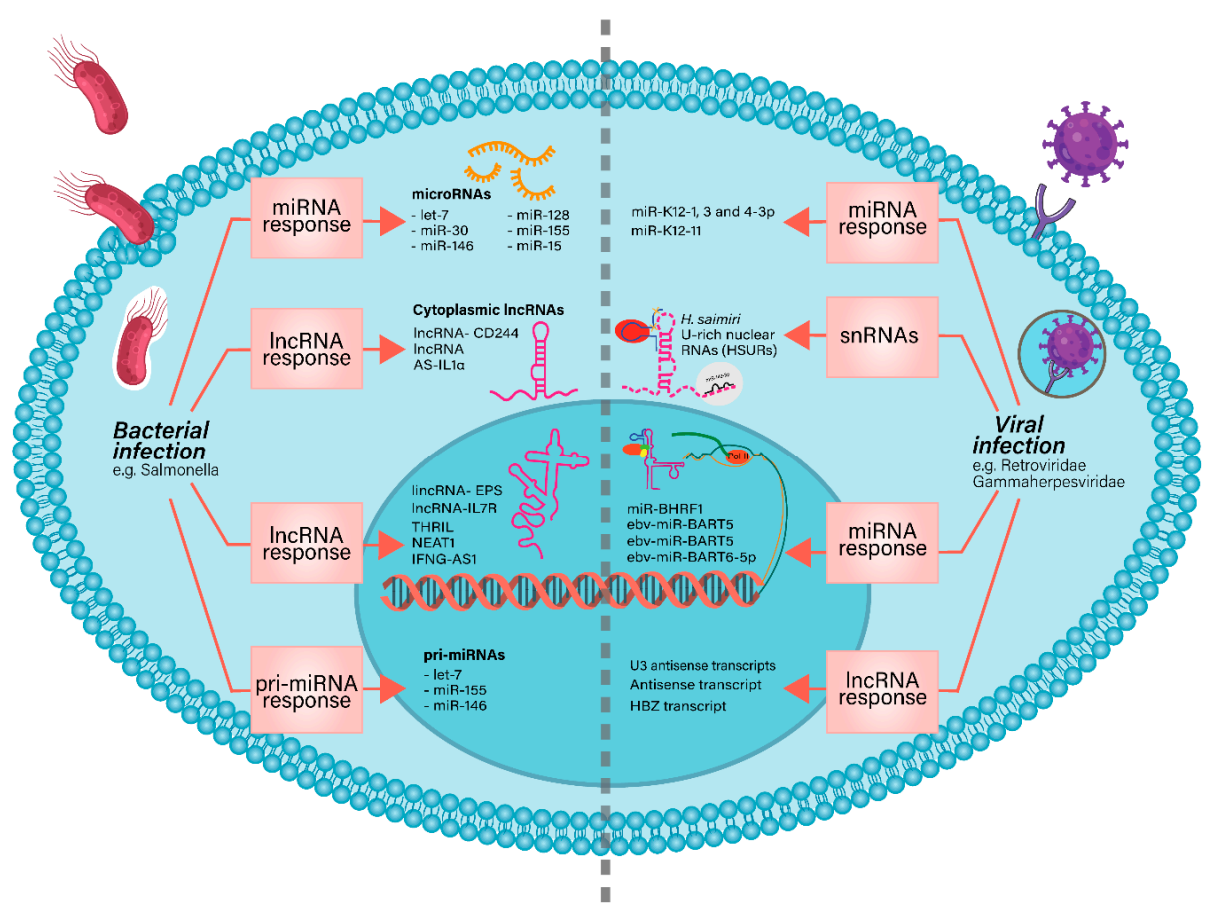

Figure 2. ncRNAs that modulate the response of a cell to bacterial or viral infections. (Left) The human ncRNA response to infections by the pathogenic bacterium Salmonella. When infections appear, a complex interplay of miRNA and lncRNA occurs, and that is utilized to respond to the Salmonella infection. For example, miRNAs miR-155 and miR-146 regulate different sets of transcripts, thus promoting or reducing inflammation. Some examples of miRNA and lncRNAs are shown in the image. (Right) The ncRNA types are involved in the host immune response against viral infections via the regulation of gene expressions. lncRNAs from the Retroviridae-antisense transcript, epigenetically regulates gene transcription, and miR-BHRF1 from Gammaherpesviridae promote cell cycle progression and proliferation and inhibit apoptosis. See more in Table $1[32,44,50-52]$.

Table 1. ncRNAs associated with bacterial or viral infections.

\begin{tabular}{|c|c|c|c|c|}
\hline ncRNA & Regulation & Target/Function & Pathogen & References \\
\hline miR-1289 & $\uparrow$ & Gastric acidity & Helicobacter pylori & {$[33]$} \\
\hline $\begin{array}{l}\operatorname{miR}-30 \mathrm{c} \\
\mathrm{miR}-30 \mathrm{e}\end{array}$ & $\uparrow$ & SUMOylation & Salmonella & [53] \\
\hline $\begin{array}{l}\operatorname{miR}-132 \\
\operatorname{miR}-26 a\end{array}$ & $\uparrow$ & Macrophage response to IFN- $\gamma$ & $\begin{array}{l}\text { Mycobacterium } \\
\text { tuberculosis }\end{array}$ & {$[54]$} \\
\hline $\begin{array}{l}\operatorname{miR}-125 b \\
\text { miR-99b } \\
\text { miR-155 }\end{array}$ & $\begin{array}{l}\uparrow \\
\uparrow \\
\downarrow\end{array}$ & Production of TNF- $\alpha$ & $\begin{array}{l}\text { Mycobacterium } \\
\text { tuberculosis }\end{array}$ & {$[55,56]$} \\
\hline Let-7f & $\downarrow$ & NF- $k B$ pathway inhibition & $\begin{array}{c}\text { Mycobacterium } \\
\text { tuberculosis }\end{array}$ & [57] \\
\hline $\operatorname{miR}-29$ & $\downarrow$ & IFN- $\gamma$ production & $\begin{array}{c}B C G \\
\text { Listeria monocytogenes }\end{array}$ & [35] \\
\hline \multirow{5}{*}{ miR-155 } & $\uparrow$ & $\begin{array}{l}\text { Activation of the } \\
\text { pro-survival Akt pathway }\end{array}$ & Listeria monocytogenes & [34] \\
\hline & $\downarrow$ & $\begin{array}{l}\text { Reduction of humoral } \\
\text { immune responses }\end{array}$ & $\begin{array}{l}\text { Citrobacter } \\
\text { rodentium }\end{array}$ & [58] \\
\hline & $\uparrow$ & $\begin{array}{c}\text { RIP1/3-related necroptosis and } \\
\text { PARP-1-mediated } \\
\text { necrosis }\end{array}$ & Salmonella & [59] \\
\hline & $\uparrow$ & Down-regulation of SHIP & $\begin{array}{l}\text { Francisella } \\
\text { tularensis }\end{array}$ & {$[60]$} \\
\hline & $\uparrow$ & $\begin{array}{l}\text { Decreased the production of IL- } 8 \text { and } \\
\text { GRO- } \alpha\end{array}$ & Helicobacter pylori & {$[33]$} \\
\hline
\end{tabular}


Table 1. Cont.

\begin{tabular}{|c|c|c|c|c|}
\hline ncRNA & Regulation & Target/Function & Pathogen & References \\
\hline miR-146a & $\uparrow$ & Suppression of nitric oxide production & $\begin{array}{l}\text { Mycobacterium } \\
\text { tuberculosis }\end{array}$ & {$[61]$} \\
\hline miR-128 & $\uparrow$ & p53 knockdown & Salmonella & {$[62]$} \\
\hline lncRNA-CD244 & $\uparrow$ & $\begin{array}{c}\text { Inhibition of TNF- } \alpha \text { and INF- } \gamma \\
\text { expression }\end{array}$ & $\begin{array}{l}\text { Mycobacterium } \\
\text { tuberculosis }\end{array}$ & {$[36]$} \\
\hline $\mathrm{NeST}$ & $\uparrow$ & IFN- $\gamma$ transcription & Salmonella enterica & {$[63]$} \\
\hline \multirow[t]{4}{*}{ NEAT1 } & $\uparrow$ & Decrease the expression of IL- 6 & $\begin{array}{l}\text { Mycobacterium } \\
\text { tuberculosis }\end{array}$ & [37] \\
\hline & $\uparrow$ & $\begin{array}{c}\text { Export of Rev-dependent instability } \\
\text { element (INS) }\end{array}$ & $\begin{array}{l}\text { Human } \\
\text { immunodeficiency virus }\end{array}$ & {$[64]$} \\
\hline & $\uparrow$ & IL-8 secretion & Influenza virus & {$[65]$} \\
\hline & $\uparrow$ & $\begin{array}{l}\text { Regulation by IRF1, IRF4, STAT1 and } \\
\text { STAT3 }\end{array}$ & SARS-CoV-2 virus & {$[66]$} \\
\hline $\operatorname{miR}-618$ & $\uparrow$ & Dysregulation of immune function & SARS-CoV-2 virus & {$[67]$} \\
\hline lncRHOXF1 & $\uparrow$ & $\begin{array}{c}\text { siRNA-mediated } \\
\text { disruption }\end{array}$ & Sendai virus & {$[38]$} \\
\hline $\begin{array}{l}\operatorname{miR}-24-1-5 p \\
\operatorname{miR}-512-5 p \\
\operatorname{miR}-4640-3 p\end{array}$ & $\uparrow$ & $\begin{array}{l}\text { Biomarkers for mild } \\
\text { dengue forms }\end{array}$ & & {$[68]$} \\
\hline $\begin{array}{c}\text { miR-383 } \\
\text { hsa-miR-21-5p }\end{array}$ & $\uparrow$ & Biomarker for mild dengue form & Dengue virus & \\
\hline $\begin{array}{l}\text { hsa-miR-146a-5p } \\
\text { hsa-miR-590-5p } \\
\text { hsa-miR-188-5p } \\
\text { hsa-miR-152-3p }\end{array}$ & $\uparrow$ & $\begin{array}{l}\text { non-invasive molecular markers for } \\
\text { detecting DENV infection }\end{array}$ & & \\
\hline miR-548g-3p & $\uparrow$ & $\begin{array}{l}\text { Suppress DENV } \\
\text { multiplication }\end{array}$ & & {$[69]$} \\
\hline $\begin{array}{l}\text { miR-133a } \\
\text { miR-484 } \\
\text { miR-744 }\end{array}$ & $\uparrow$ & $\begin{array}{l}\text { Downregulate DENV } \\
\text { replication }\end{array}$ & & {$[70]$} \\
\hline $\operatorname{miR}-122$ & $\uparrow$ & Stabilizes the HCV genome & & {$[68]$} \\
\hline lncRNA-CMPK2 & $\uparrow$ & $\begin{array}{l}\text { Interferon response } \\
\text { modulation }\end{array}$ & Hepatitis $C$ virus & {$[71]$} \\
\hline $\begin{array}{c}\text { GAS5 } \\
\text { miR-25 }\end{array}$ & $\uparrow$ & $\begin{array}{l}\text { Decoy of HCV NS3 protein } \\
\text { HCV reduces their levels offsetting their }\end{array}$ & & {$[72]$} \\
\hline $\begin{array}{c}\operatorname{miR}-130 a / b \\
\text { let-7a }\end{array}$ & $\downarrow$ & $\begin{array}{l}\text { antiviral } \\
\text { capacity }\end{array}$ & & {$[73,74]$} \\
\hline $\begin{array}{l}\text { BART } \\
\text { BHLF1 }\end{array}$ & $\uparrow$ & Tumorigenesis & Epstein-Barr virus & [75] \\
\hline miR-141 & $\uparrow$ & Pro-viral effect & Enterovirus 71 & [76] \\
\hline miR-485-5p & $\uparrow$ & $\begin{array}{c}\text { Suppression of the antiviral response } \\
\text { and enhanced } \\
\text { viral replication }\end{array}$ & $\begin{array}{l}\text { Newcastle disease } \\
\text { virus }\end{array}$ & [77] \\
\hline $\operatorname{miR}-148$ & $\uparrow$ & $\begin{array}{c}\text { Valuable biomarkers for } \\
\text { severe influenza virus } \\
\text { infections }\end{array}$ & & [78] \\
\hline $\begin{array}{c}\operatorname{miR}-31 \\
\text { miR-29a }\end{array}$ & $\downarrow$ & & Influenza virus & \\
\hline $\begin{array}{l}\operatorname{miR}-34 c-3 p \\
\operatorname{miR}-29 a-3 p\end{array}$ & $\uparrow$ & Biomarker & & {$[79,80]$} \\
\hline $\begin{array}{l}\operatorname{miR}-30 c-5 p \\
\text { miR-181a-5p } \\
\text { miR-323 }\end{array}$ & $\downarrow$ & Biomarkers & & {$[79,80]$} \\
\hline $\begin{array}{c}\operatorname{miR}-491 \\
\operatorname{miR}-654 \\
\operatorname{miR}-146 a\end{array}$ & $\uparrow$ & $\begin{array}{l}\text { Inhibition of influenza } \\
\text { virus replication }\end{array}$ & & [81] \\
\hline
\end{tabular}


Table 1. Cont.

\begin{tabular}{|c|c|c|c|c|}
\hline ncRNA & Regulation & Target/Function & Pathogen & References \\
\hline $\begin{array}{c}\text { MALA1 } \\
\text { LINC01426 }\end{array}$ & $\uparrow$ & $\begin{array}{l}\text { Activate HIV-1 replication and } \\
\text { reactivates HIV-1 from latency }\end{array}$ & & {$[82,83]$} \\
\hline $\begin{array}{l}\text { 7SKRNA NEAT1 } \\
\text { NRON }\end{array}$ & $\uparrow$ & Repress HIV-1 infection & $\begin{array}{c}\text { Human } \\
\text { immunodeficiency virus }\end{array}$ & \\
\hline GAS5 & $\downarrow$ & Inhibits HIV-1 replication & & [83-85] \\
\hline HEAL & $\uparrow$ & $\begin{array}{l}\text { Regulates HIV-1 } \\
\text { transcription }\end{array}$ & & {$[83,86]$} \\
\hline LINC00173 & $\downarrow$ & $\begin{array}{l}\text { Dysregulates the } \\
\text { immune response }\end{array}$ & & {$[83,87]$} \\
\hline \multirow[t]{2}{*}{ MALAT-1 } & $\uparrow$ & Cervical cancer cell growth & Human papilloma virus & [88] \\
\hline & $\uparrow$ & $\begin{array}{l}\text { Induction of unfolded } \\
\text { protein response }\end{array}$ & Flaviviruses & [89] \\
\hline miR-155 & $\uparrow$ & $\begin{array}{l}\text { Biomarker for poor } \\
\text { prognosis }\end{array}$ & & {$[90,91]$} \\
\hline $\operatorname{miR}-218$ & $\downarrow$ & $\begin{array}{l}\text { Inhibition of cancer cell migration and } \\
\text { invasion }\end{array}$ & Human papilloma virus & {$[90,91]$} \\
\hline $\operatorname{miR}-195$ & $\downarrow$ & Biomarker for advanced clinical stages & & [91-93] \\
\hline miR-375 & $\downarrow$ & $\begin{array}{c}\text { Biomarker for poor } \\
\text { prognosis }\end{array}$ & & {$[91,94]$} \\
\hline $\begin{array}{l}\operatorname{miR}-34 a \\
\operatorname{miR}-23 b\end{array}$ & $\downarrow$ & $\begin{array}{l}\text { Increased migration of } \\
\text { cervical cancer cell lines }\end{array}$ & & {$[91,95]$} \\
\hline
\end{tabular}

Both bacterial and viral infections can alter the expression of miRNAs and lncRNAs [96], which are supposed to regulate the inflammatory response of immune cells toward infections. For example, miR-99b plays a crucial role in the pathogenesis of M. tuberculosis infection, and the downregulation of miR-99b in dendritic cells upregulates different proinflammatory cytokines, such as IL-6, IL-12, and IL-1 $\beta$ [55]. TNF- $\alpha$ is an important target with a key role in the host defense response to $M$. tuberculosis infection. Thus, $\mathrm{M}$. tuberculosis can inhibit TNF- $\alpha$ production via modulation of the miRNA host response and accelerate infection by facilitating replication in the host cell $[55,97]$. M. tuberculosis also decreases the production of TNF- $\alpha$ by regulating miR-125b, miR-155, and miR-99b [58]. Finally, miRNA let-7 regulates the immune response to M. tuberculosis infection via A20, an inhibitor of the NF-KB pathway [54].

\subsection{NcRNAs Involved in Bacterial Infections}

In another case, miR-29 expression was found downregulated in mice infected with Listeria monocytogenes or Mycobacterium bovis bacillus Calmette-Guérin (BCG), the downregulation being observed in IFN- $\gamma$-producing natural killer cells, CD4(+) T cells, and CD8(+) T cells [35].

miR-155 is another important ncRNA that can trigger a powerful immune response against bacterial pathogens. miR-155 was required for optimal CD8+ T-cell responses to Listeria monocytogenes [34] but had a slower clearance upon Citrobacter rodentium infection [58]. In macrophages, miR-155 upregulation by Salmonella infection was mediated by RIP1/3related necroptosis and PARP-1-mediated necrosis, leading to macrophage death [59]. The release of proinflammatory cytokines in human monocytes infected with Francisella tularensis was found positively regulated by miR-155 [60]. Moreover, miR-155-containing exosomes were found to be important adjuvants for improving vaccine efficacies and, also, to combat infections like the one produced by Helicobacter pylori [98]. Furthermore, miR-155 decreased the production of IL-8 and GRO- $\alpha$ in gastric epithelial cells after $H$. pylori infection [99]. Toll-like receptors (TLRs) are germline-encoded pattern recognition receptors (PRRs) known as key players in host cell identification and responses to bacterial and viral agents [100]. Studies regarding the biological function of miR-146a during mycobacterial 
infection proved that it promotes mycobacterial survival in macrophages through the suppression of nitric oxide production [61]. Recent evidence has revealed mir-133a-1-3p and mir-133a-2-3p as potential circulating miRNAs associated with Gram-positive bacterial infections [101].

In vivo studies found that the intragastric delivery of anti-miR-128 enhances M-CSFmediated macrophage recruitment and suppresses Salmonella infection, with miR-128 expression being induced via the p53 signaling pathway [62].

There is growing evidence that lncRNAs can act as positive or negative effectors on antibacterial immunity. Thus, the host uses lncRNAs to protect itself from microbial invasion by regulating the immune-related genes at the epigenetic, transcriptional, and post-transcriptional levels. However, bacteria can also control the host signaling pathways by guiding the host lncRNAs to evade immune clearance [32]. In $M$. tuberculosis infection, lncRNA-CD244 is upregulated by the T-cell inhibitory molecule CD244 and functions as an epigenetic inhibitor of TNF- $\alpha$ and INF- $\gamma$ expression [36]. Salmonella enterica pathogenesis was decrease by lncRNA Nettoie Salmonella pas Theiler's (NeST), which induces IFN- $\gamma$ transcription, especially in activated CD8+ T cells [63]. In peripheral blood mononuclear cells (PBMCs) from patients infected with M. tuberculosis, NEAT1 was found upregulated, decreasing the expression of IL- 6 and increasing the replication of M. tuberculosis, indicating an antituberculosis role of NEAT1 [37]. Intracellular bacteria, such as Salmonellae, Mycobacteria, Helicobacter, and Listeria, were observed to interfere with the expression of lncRNAs in order to alter host cell immune defense systems [32].

\subsection{NcRNAs in Viral Infections}

Some viruses can also produce miRNAs necessary for their survival and for evading host immune responses. The mechanisms involved in these processes consist of viral replication [102], host immune system evasion [103], viral latency, and the regulation of host and viral genes [104]. The interaction between viral RNAs and host miRNAs is proven to be necessary for viral RNA stability, replication, or other pathogenesis-associated processes [105]. Furthermore, viruses can counteract miRNA antiviral defenses by releasing specific virulence factors that are known as viral suppressors of RNA silencing (VSRs) [106]. The degradation of miRNAs after a viral infection requires the $3^{\prime}$-end addition of nontemplated nucleotides by tailing enzymes, then degradation by exonucleases [107].

Interestingly, miRNAs can inhibit SARS-CoV-2 infection by blocking viral replication, cellular receptors, and the function of viral proteins [108]. In terms of COVID-19 treatment options, miR-618 can be an important target, as it regulates the immune responses and viral replication [67]. Likewise, inflammation-associated miR-31-5p was found to be one of the most upregulated miRNAs in the early stages of COVID-19 [109]. lncRNAs have been also identified to be involved in virus replication, promoting viral infection. Viral genes can regulate the levels of cellular lncRNAs by modulating the protein-encoding gene expression. Additionally, cellular lncRNAs are used by viruses to regulate the expression and function of both host and viral genes [110]. Herpesviruses produce persistent infections. In this case, macrovesicles transfer viral and cellular factors, allowing the virus to regulate the cellular microenvironment, with advantages for both the virus and the host [75]. Most induced lncRNAs have been observed as direct targets of IFN signaling or IFN stimulated genes (ISGs) in viral infections, as is the case of mouse macrophages infected with vesicular stomatitis virus (VSV) [111]. The viral infections identified in some organs, such as the placenta in mammals, are also linked to some lncRNAs [112].

In a recent study, it was observed that lncRHOXF1, which triggers the host response to viral infections, increases in human trophectoderm progenitor cells. However, lncRHOXF1 can be disrupted by siRNA during infection, decreasing the expression of viral response genes and, finally, enhancing virus replication [38]. The upregulation of NEAT1 was observed in T cells infected by HIV-1, the downregulated NEAT1 being responsible for the increase of HIV-1 replication and, also, for the delivery of HIV-1 mRNA 
from the nucleus to cytoplasm [64]. Influenza virus and HSV infection also induced NEAT1 expression, and cytokines such as IL-8 promoted the action of NEAT [65]. The expression of NEAT1 was also increased in the lung tissues of patients infected with SARS-CoV-2 virus [66]. IncRNA-CMPK2 increased Hepatitis $C$ virus replication while being strongly upregulated in a group of $\mathrm{HCV}$-infected human livers, enhancing its role in the modulation of the interferon response [71]. Hepatitis $C$ virus replication was inhibited via GAS5 by targeting the viral NS3 protein, the innate immune response being poor [72]. Zhang et al. observed that the Epstein-Barr virus (EBV) is able to encode its own viral lncRNAs (BART lncRNAs and BHLF1 lncRNA), which are involved in tumorigenesis-associated processes [75].

Nevertheless, some miRNAs could be found present in both bacterial and viral infections while also being highly involved in multiple biological processes (Table 2).

Table 2. Common miRNAs for both bacterial and viral infections.

\begin{tabular}{|c|c|c|c|c|c|}
\hline \multirow[t]{2}{*}{ ncRNA } & \multicolumn{2}{|c|}{ Target/Function } & \multicolumn{2}{|c|}{ Pathogen Regulation } & \multirow[t]{2}{*}{ References } \\
\hline & Viral & Bacterial & Viral & Bacterial & \\
\hline miR-146a & $\begin{array}{l}\text {-Inhibition of influenza virus } \\
\text { replication; } \\
\text {-Unknown }\end{array}$ & $\begin{array}{l}\text { Suppression of nitric oxide } \\
\text { production }\end{array}$ & $\begin{array}{c}\uparrow \text { Influenza virus } \\
\uparrow \downarrow \text { Hepatitis C virus }\end{array}$ & $\begin{array}{l}\uparrow \text { Mycobacterium } \\
\text { tuberculosis }\end{array}$ & {$[61,81]$} \\
\hline miR-155 & $\begin{array}{c}\text { Biomarker for poor } \\
\text { prognosis, IFN-related } \\
\text { molecule }\end{array}$ & $\begin{array}{c}\text {-Production of } \\
\text { TNF- } \alpha \\
\text {-Activation of the } \\
\text { pro-survival Akt } \\
\text { pathway } \\
\text {-Reduction of } \\
\text { humoral immune } \\
\text { responses } \\
\text {-RIP1/3-related } \\
\text { necroptosis and } \\
\text { PARP-1-mediated } \\
\text { necrosis }\end{array}$ & $\uparrow$ Hepatitis $C$ virus & $\begin{array}{c}\downarrow \text { Mycobacterium } \\
\text { tuberculosis } \\
\uparrow \text { Listeria } \\
\text { monocytogenes } \\
\downarrow \text { Citrobacter } \\
\text { rodentium; } \\
\uparrow \text { Salmonella }\end{array}$ & {$[55,61,90]$} \\
\hline miR-16 & Increased production of ROS & Unknown & $\downarrow$ SARS-CoV-2 & $\downarrow$ C. trachomatis & {$[113,114]$} \\
\hline $\operatorname{miR}-30 \mathrm{c}$ & Biomarker & SUMOylation & $\downarrow$ Influenza virus & $\uparrow$ Salmonella & {$[53,79]$} \\
\hline NEAT1 & $\begin{array}{c}\text { Repress HIV-1 } \\
\text { infection, export of } \\
\text { Rev-dependent } \\
\text { instability element (INS) }\end{array}$ & $\begin{array}{c}\text { Decrease the } \\
\text { expression of IL-6 }\end{array}$ & $\begin{array}{c}\uparrow \text { Human } \\
\text { immunodeficiency } \\
\text { virus }\end{array}$ & $\begin{array}{l}\uparrow M y c o b a c t e r i u m \\
\text { tuberculosis }\end{array}$ & {$[37,64]$} \\
\hline miR-133a & $\begin{array}{l}\text { Downregulate DENV } \\
\text { replication }\end{array}$ & $\begin{array}{c}\text { Biomarker-circulating } \\
\text { miRNA }\end{array}$ & $\uparrow$ Dengue virus & $\begin{array}{l}\text { Gram-positive bacterial } \\
\quad(\text { mir-133a-1-3p } \\
\text { mir-133a-2-3p) }\end{array}$ & {$[70,101]$} \\
\hline let-7 & $\begin{array}{l}\text {-HCV reduces their } \\
\text { levels offsetting their } \\
\text { antiviral capacity; } \\
\text {-TLR4 and STAT3 } \\
\text { signaling }\end{array}$ & $\begin{array}{c}\text {-Induced acute } \\
\text { inflammation } \\
\text { characterized by } \\
\text { neutrophil infiltration }\end{array}$ & $\begin{array}{c}\downarrow \text { Hepatitis C virus } \\
\text { (let-7a) } \\
\downarrow \text { Hepatitis B virus } \\
\text { (let-7) }\end{array}$ & $\downarrow$ Helicobacter pylori & {$[73,74,114,115]$} \\
\hline $\operatorname{miR}-125 b$ & TLR2/MyD88 signaling & Production of TNF- $\alpha$ & $\downarrow$ Hepatitis C Virus & $\begin{array}{c}\uparrow M y c o b a c t e r i u m \\
\text { tuberculosis }\end{array}$ & {$[55,56,114]$} \\
\hline $\operatorname{miR}-29$ & $\begin{array}{l}\text { Biomarker for severe } \\
\text { influenza virus } \\
\text { infections }\end{array}$ & $\begin{array}{l}\text {-IFN- } \gamma \text {-production; } \\
\text {-Unknown }\end{array}$ & $\begin{array}{l}\downarrow \text { Influenza virus } \\
\quad(\text { miR-29a) }\end{array}$ & $\begin{array}{l}\downarrow B C G \text { Listeria } \\
\text { monocytogenes } \\
\downarrow C \text {. trachomatis }\end{array}$ & {$[35,78,114]$} \\
\hline $\begin{array}{l}\operatorname{miR}-372 \\
\operatorname{miR}-373\end{array}$ & $\begin{array}{l}\text { NFIB-dependent } \\
\text { signaling }\end{array}$ & $\begin{array}{l}\text { Cell cycle and } \\
\text { apoptosis }\end{array}$ & $\uparrow$ Hepatitis B Virus & $\downarrow$ Helicobacter & {$[49,114]$} \\
\hline $\operatorname{mir}-122$ & $\begin{array}{l}\text { Stabilizes the HCV } \\
\text { genome }\end{array}$ & Unknown & $\uparrow$ Hepatitis C Virus & $\begin{array}{l}\downarrow \text { Enterobacteriaceae } \\
\text { spp. }\end{array}$ & {$[68,114]$} \\
\hline $\operatorname{miR}-223$ & $\begin{array}{c}\text { Antiviral-target } \\
\text { Indirect: STMN1 mRNA }\end{array}$ & Unknown & $\begin{array}{l}\text { DENV-2 (strain } \\
\text { TR1751) }\end{array}$ & $\begin{array}{l}\uparrow \text { Enterobacteriaceae } \\
\text { spp. }\end{array}$ & {$[68,114]$} \\
\hline $\operatorname{miR}-125 b$ & $\begin{array}{l}\text { TLR2/MyD88 signaling/ } \\
\text { Immune response } \\
\text {-STAT3 signaling; }\end{array}$ & $\begin{array}{c}\text { Directly targets mRNA of } \\
\text { TNF }\end{array}$ & $\downarrow$ Hepatitis C Virus & $\uparrow M y c o b a c t e r i a$ & {$[49,114]$} \\
\hline miR-21 & $\begin{array}{l}\text {-Non-invasive } \\
\text { molecular markers for } \\
\text { detecting DENV } \\
\text { infection. }\end{array}$ & Immune response & $\begin{array}{l}\uparrow \text { Hepatitis B virus } \\
\uparrow \text { Dengue virus } \\
\text { hsa-miR-21-5p }\end{array}$ & $\uparrow$ Salmonella & {$[49,68,114]$} \\
\hline
\end{tabular}




\subsection{Other ncRNAs Involved in Bacterial or Viral Infections}

Among the wide class of ncRNAs, we can also find piRNAs, which are an animalspecific group of small silencing RNAs that bear the $2^{\prime}$-O-methyl-modified $3^{\prime}$ termini and regulate the synthesis of PIWI proteins. While other types of ncRNAs such as miRNAs and siRNAs are derived from double-stranded precursors, piRNA biogenesis starts from long single-stranded transcripts. With respect to their biologic activity, piRNAs are primarily involved in regulating genome stability, but they were recently found to be associated with different bacterial and viral infections [116]. Hence, piRNA expression patterns were found to be correlated with a metastatic stage of HPV-positive head and neck squamous cell carcinoma (HNSCC), which affects over 550,000 individuals each year [117]. Recent studies have confirmed the status of piRNAs as new players in pulmonary tuberculosis pathogenesis, which is caused by $M$. tuberculosis bacteria, due to their involvement in transcription, protein binding, and immunity $[118,119]$.

While initially thought of as byproducts of aberrant splicing, circRNAs have recently regained their status as a special type of evolutionarily conserved, covalently closed singlestranded RNA and are now highly investigated for their biological roles: the regulation of gene expression, protein encoding, protein activity inhibition, etc. [120]. Furthermore, as confirmed by a recent study, circRNAs are also found to be associated with both viral infections (virusderived circRNAs: HPV16 circE7, HBV circRNA, MHV68 circM11_ORF69, KSHV circvIRF4, EBV circ_RPMS1, circBARTs, circvIRF4, circEBNA_U, etc.) and with the host immune response against viral infections (host circRNAs: hsa_circ_0000479, hsa_circ_0004812, hsa_circ_0005389, hsa_circ_0003863, hsa_circ-GATAD2A, hsa_circRNA3046, etc.), where they regulate both viral replication and the host antiviral immune responses [121]. Likewise, when it comes to bacterial infections, circRNAs do participate in associated pathogenesis, such as in pulmonary tuberculosis, where hsa_circRNA_001937 is upregulated and hsa_circRNA_102101 downregulated, highlighting their potential as valuable clinical biomarkers [122].

It is already well-known that most viruses rely on their host cell translation machinery in order to efficiently synthesize their own viral proteins. In fact, recent evidence has highlighted diverse implications of host transfer RNAs (tRNAs) in the process of virus replication and associated pathogenesis. For instance, different RNA viruses (IAV, HIV-1, $\mathrm{NiV}$, and $\mathrm{HAV}$ ) manipulate host tRNA pools to favor viral protein translation. Furthermore, the formation of tRNA-derived fragments upon infection was also found to promote viral replication. It seems that viruses can pursue these processes by either adjusting host cell tRNAs to specifically match the viral codon usage or by shifting their viral codon usage towards the host codon [123].

\section{Reactive Oxygen Species in Bacterial and Viral Infections}

Whenever a potentially harmful pathogen is spotted, one of the early responses of host innate immunity is the production of ROS. Free oxygen radicals are highly toxic to both bacterial and viral pathogens, usually being produced to prevent the colonization of certain pathogens. As a part of the intracellular redox profile, ROS are also involved in the orchestration of a wide variety of signaling networks. "Oxidative stress" describes a physiological state where oxygen radicals exceed those of antioxidants, hence potentiating apoptosis, tumorigenesis, and immune responses [124-127]. Here, we describe the implications of ROS in different bacterial and viral infections accordingly to multiple studies found in the scientific literature.

One research study reports that kinases Mst1 and Mst2 play an important role in the production of ROS by controlling mitochondrial trafficking and mitochondrion-phagosome juxtaposition. Mitochondria need to be juxtaposed to phagosomes in order to synergistically generate sufficient ROS in phagocytes to further ensure a proper microbial counteraction. It appears that Mst1 and Mst2 activate Rac GTPase in order to assemble the TRAF6-ECSIT complex required for mitochondrial recruitment to phagosomes. Sometimes, the Rac form is inactive (e.g., mutant Rac2D57N) and the ROS production levels are low, which elevates the susceptibility to bacterial infection [128]. 
In another study, ROS were reported to possess a highly antimicrobial effect against bacterial, viral, and fungal infections, as it can prevent and break down biofilms. These findings promote ROS as a highly suitable player in different chronic inflammatory diseases: chronic wounds, ulcers, burns, and, especially, in bacterial infection cases when antibiotics become ineffective. Furthermore, ROS-positive effects are also supported by early clinical data, as they could be used to reduce bacterial infection risks in the treatment of skin and soft tissue lesions [129].

Some opportunistic pathogens, such as Acinetobacter baumannii, are associated with different nosocomial infections, like bacteremia, pneumonia, meningitis, urinary tract, or wound infections. The production of ROS within the phagolysosome has effective antimicrobial proprieties. Hence, in A. baumannii infections, ROS contributes to the bactericidal functions of neutrophiles and macrophages, playing a key role in the host defense, with toxic effects against the pathogens. However, the uncontrolled regulation of mitochondria-derived ROS could lead to chronic inflammation and pathologies during infections [130,131].

Nicotinamide adenine dinucleotide phosphate (NADPH) oxidase also produces important amounts of ROS that are engaged in the antimicrobial host defense and inflammation system. When absent or insufficient in humans, recurrent or severe bacterial infections are usually around the corner. Hence, the discharge of high concentrations of ROS helps with the clearance of invading bacteria. Host immune cells, such as neutrophils, will also release considerable amounts of ROS at the site of infection [132]. Furthermore, in the case of chronic granulomatous disease (CGD), an inherited condition characterized by recurrent bacterial and fungal infections, the impaired host defense is due to the defective production of ROS by phagocytes. This is caused by mutations in genes encoding the NADPH oxidase complex, but the pathogen, however, depends on the geographical area. In North America and Europe, the main bacteria responsible for such diseases are S. aureus, Burkholderia cepacia, Serratia marcescens [133-136].

Still, some studies indicate the negative effects of excessive ROS levels for host organisms. For example, in H. pylori infections, activated neutrophils ensure high amounts of ROS, but it seems that the bacteria itself produces ROS. Hence, researchers have reported that such $\mathrm{H}$. pylori-induced ROS biogenesis could affect gastric epithelial cell signal transduction, resulting in gastric carcinogenesis [137].

Therefore, as byproducts of cellular metabolism, ROS can be either beneficial or detrimental to the host cells, depending on their concentration. Besides the alreadyrenowned antimicrobial proprieties of ROS, they seem to also have an opposite effect when it comes to viral pathogenesis. Several viral infections cause elevated oxidative stress levels, and some viruses can use this ROS excess to enhance their pathogenesis. Some examples of such viral pathogens are: SARS coronavirus and rabies virus, rhinovirus, West Nile virus and vesicular stomatitis virus, hepatitis $C$ virus, human immunodeficiency virus, and influenza virus [138].

Despite all the modern therapies available, viral infections still inflict an unacceptable grade of morbidity and mortality, as they are the primary cause of pneumonia. However, recent findings highlighted the fact that lung cells can protect themselves against viral pathogens, even in the absence of leukocytes. It seems that this protection is due to an induction of ROS, apparently without reliance on type I interferon signaling [139].

Virus-induced oxidative stress is essential for both the viral life cycle and its pathogenesis. To counteract the elevated levels of ROS induced by viral infections, host cells activate an antioxidative defense system pathway called erythroid 2p45-related factor 2 (Nrf2) that facilitates cytoprotection. Recently, a series of studies reported the capacity to positively or negatively regulate the Nrf2 pathway and the ROS levels via certain viruses. Furthermore, it seems that such a modulation of the host antioxidative response turned out to be essential for the progression of several viral diseases (Table 3) [140]. 
Table 3. Regulations of the Nrf2 pathway by pathogenic viruses.

\begin{tabular}{|c|c|c|c|c|}
\hline Virus & Disease & ROS & Nfr2 & Reference \\
\hline \multirow[t]{2}{*}{ MoMuLV ts1 } & Neurodegenerative disease & $\mathrm{H}_{2} \mathrm{O}_{2} \downarrow$ & $\uparrow$ & {$[140,141]$} \\
\hline & Neurodegenerative disease & $\uparrow$ & $\uparrow$ & {$[140,142,143]$} \\
\hline \multirow{3}{*}{ HIV } & Neurocognitive disorder & $\mathrm{H}_{2} \mathrm{O}_{2} \uparrow$ & $\uparrow$ & {$[140,144]$} \\
\hline & AIDS & $\uparrow$ & $\uparrow$ & {$[140,144-146]$} \\
\hline & Respiratory disorder & $\uparrow$ & $\downarrow$ & {$[140,147]$} \\
\hline $\mathrm{HCV}$ & HCC & ND & $\uparrow$ & {$[140,148]$} \\
\hline Influenza & Respiratory disease & $\uparrow$ & Nuclear localization $\uparrow$ & {$[140,149]$} \\
\hline RSV & Respiratory disease & $\uparrow$ & $\downarrow$ & {$[140,150]$} \\
\hline $\mathrm{HBV}$ & Viral hepatitis & $\downarrow$ & $\uparrow$ & [140] \\
\hline HSV & Encephalitis neurotoxicity & $\uparrow$ & $\uparrow$ & {$[140,151,152]$} \\
\hline HCMV & Congenital abnormalities & $\uparrow$ & $\uparrow$ & {$[140,153]$} \\
\hline KSHV & Sarcoma & $\uparrow$ & Nuclear localization $\uparrow$ & {$[140,154]$} \\
\hline DENV & Fever & $\uparrow$ & $\uparrow$ & {$[140,155]$} \\
\hline
\end{tabular}

However, the presence of certain bacteria and viruses can cause the activation of host ROS generation systems that further exert antibacterial and antiviral effects (Table 4).

Table 4. Common host ROS generation systems for both viral and bacterial infections.

\begin{tabular}{|c|c|c|c|c|c|}
\hline \multirow[t]{2}{*}{ ROS Generator } & \multicolumn{2}{|c|}{ Effect of $\uparrow$ ROS } & \multicolumn{2}{|c|}{ Pathogen Trigger } & \multirow[t]{2}{*}{ Reference } \\
\hline & Virus & Bacteria & Virus & Bacteria & \\
\hline Mitochondrial ROS & $\begin{array}{c}\text { Damage the mtDNA, } \\
\text { membrane lipid } \\
\text { permeability, release of } \\
\text { cytochrome } \mathrm{C} \text { and apoptosis }\end{array}$ & $\begin{array}{c}\text {-Bactericidal; } \\
\text {-Stimulation of TLR9 by } \\
\text { CpG-containing DNA and } \\
\text { subsequent ROS production }\end{array}$ & Hepatitis $C$ virus & $\begin{array}{c}\text { Salmonella } \\
\text { typhimurium } \\
\text { Staphylococcus aureus }\end{array}$ & [156] \\
\hline ER stress & \multicolumn{2}{|c|}{$\begin{array}{l}\text { Boosts proinflammatory cytokine } \\
\text { production via MAPK-killing }\end{array}$} & \multicolumn{2}{|c|}{ both } & [156] \\
\hline $\begin{array}{l}\text { NADPH oxidase } \\
\text { (NOX) }\end{array}$ & $\begin{array}{l}\text { Induce activation of } \\
\text { Capsase- } 3 \text { and } \\
\text { apoptosis }\end{array}$ & $\begin{array}{c}\text { Promote oxidative and } \\
\text { nonoxidative mechanisms of } \\
\text { microbe } \\
\text { elimination }\end{array}$ & \multicolumn{2}{|c|}{ both } & [39] \\
\hline $\begin{array}{l}\text { NOX2-derived } \\
\text { ROS in } \\
\text { macrophages }\end{array}$ & \multicolumn{2}{|c|}{$\begin{array}{l}\text { Produce ROS in the phagosomal membrane, resulting in } \\
\text { elimination of the pathogen }\end{array}$} & Influenza A virus & $\begin{array}{l}\text { Escherichia coli } \\
\text { L. mono- } \\
\text { cytogenes }\end{array}$ & {$[156,157]$} \\
\hline NOX4 & $\begin{array}{l}\text { Induction of } \\
\text { superoxide and } \mathrm{H}_{2} \mathrm{O}_{2} \text { in } \\
\text { hepatocytes }\end{array}$ & $\begin{array}{c}\text { Induction of superoxide and } \\
\mathrm{H}_{2} \mathrm{O}_{2} \text { in lung cell and } \\
\text { nuclear ROS } \\
\text { generation }=> \\
\text { histone acetylation and } \\
\text { chromatin } \\
\text { remodeling }\end{array}$ & HCV infection & P. aeruginosa & {$[156,158]$} \\
\hline NF- $k$ B pathway & $\begin{array}{c}\text { Inducing } \\
\text { ROS-upregulation of antiviral } \\
\text { genes in lymphocytes }\end{array}$ & $\begin{array}{c}\text { Adjust } \\
\text { inflammation through } \\
\text { neutrophils that modulating } \\
\text { inflammation }\end{array}$ & $\begin{array}{l}\text { Japanese } \\
\text { encephalitis virus } \\
\text { (JEV) }\end{array}$ & C. albicans & {$[156,159]$} \\
\hline $\begin{array}{l}\text { Activation of } \\
\text { NLRP3 } \\
\text { inflammasome }\end{array}$ & \multicolumn{2}{|c|}{ Antiviral/antibacterial activity } & $\begin{array}{l}\text { RNA viruses DNA } \\
\text { viruses }\end{array}$ & bacterial RNA & {$[156,160]$} \\
\hline
\end{tabular}

\section{The Interplay between ncRNAs and ROS in Bacterial and Viral Infections}

The regulatory role of cellular miR-17 in ROS generation has been observed in microglial cells exposed to the HIV-1 Tat C protein, the increasing levels of ROS production leading to the activation of microglial cells and intensification of cytokine production [161]. The suppression of miR-16 is a major contribution to lung destruction in patients with severe SARS-CoV-2 infections due to the increased production of ROS; the upregulation of miR-16 can be taken into account to inhibit the detrimental symptoms of COVID-19 [113].

lncRNA HOTAIRM1 induces increased levels of ROS during latent HIV infection and promotes myeloid-derived suppressor cell expansion, contributing to HIV progression 
by impairing antiviral immunity [162]. The expressions of HOTAIRM1 are significantly upregulated in CD33+ myeloid cells derived from hepatitis $\mathrm{C}$ virus (HCV)-infected patients, and this promotes the activation of ROS [162]. Regarding miR-155, its increased expression was found linked to enhanced ROS production by targeting SHIP1 in macrophages after BCG infection [163]. Additionally, miR-155 negatively regulates ROS-triggered apoptosis during MTB infection, as well as the suppression of cytokine signaling 1 (SOCS1) and inhibits tumor necrosis factor alpha (TNF-a) [164]. Bacterial pulmonary infections are common in lung cancer patients and high levels of ROS due to TLR4 activation promoting primary lung cancer development through miR-21 [165]. In infected macrophages, the elimination of M. tuberculosis requires the presence of miR-27b that induces cell apoptosis through the p53-ROS-signaling pathway [166]. An enhanced expression of the miR-302/367 cluster increases the clearance of P. aeruginosa by the control of ROS production via regulation of the mitophagy response against infection. The production of ROS can be decreased by the inhibition of NF-kB in macrophages, which may also reduce the cell damages produced by P. aeruginosa infection and maintain cellular homeostasis [167]. E. faecalis infection causes the downregulation of miR-17-92 cluster expression, a consequence of ROS stimulation that induces DNA damage [168]. Apoptotic-regulating miRNAs, such as miR-200a, are downregulated by the influenza virus but, due to the ROS conditions, are observed to enhance the antioxidant pathway in infected mice [169]. Epstein-Barr virus (EBV) nuclear antigen 1 (EBNA1) is a viral protein that induces malignant transformation through a modulated increase of ROS and the associated production of cell viability by the regulation of miRNA34a [170]. The level of ROS is regulated through the HOTAIRSirt1 signaling pathway in liver cells infected by Hepatitis C virus [171] BCG infection, which induces macrophage cell apoptosis and an increase of LincRNA-Cox2 expression, respectively, of ROS secretion [172]. Finally, in hepatitis B virus-related hepatocellular carcinoma, the lncRNA AX800134 was identified, an oncogenic factor whose upregulation could be reversed by ROS scavenger pyrrolidine dithiocarbonate (PDTC) [173].

\section{Conclusions}

Despite all of the collaborative, scientific efforts, bacterial and viral infectious diseases are still emerging as one of the leading causes of morbidity and mortality worldwide. None of the current diagnosis methods can rapidly and accurately discriminate between those two types of infections, and this is one of the reasons why clinicians tend to misguide proper diagnoses. These hard-to-avoid medical errors further increase the antimicrobial resistance and even cause more harm, or death, in some instances.

However, as recent advances in the field of genomics have allowed the discovery of ncRNAs, which have proven to be valuable players in both the host immune response and bacterial and viral pathogenesis, we are steadily stepping in the right direction. The implication of such ncRNAs (miRNAs and lncRNAs) is gaining more and more interest from the scientific community, especially since they have quite the potential to become the building blocks for better diagnosis and treatment options in infectious diseases.

As future directions regarding the use of ncRNAs in the management of bacterial or viral infections, using miRNAs and lncRNAs for the development of novel mRNA therapeutics, such as mRNA-based vaccines, shifts perspectives towards using ncRNAs for establishing novel and innovative therapeutic solutions [174-176]. Regarding the ROS associated with different bacterial or viral infections, extensive research must be conducted in order to uncover their potential in the development of novel and efficient diagnostic and treatment methods. One future lead might be their usage as therapeutic measures against viral infections, since they can impair RNA integrity faster than other molecules [177]. Therefore, encouragement to further pursuit research on the roles of ncRNAs and ROS in bacterial and viral infections represents an important message, as they can reshape the way we currently manage such cases in clinical setups.

Finally, gearing up healthcare providers with the proper tools for the early and efficient diagnosis of infectious diseases has become an urgent, global need. Therefore, the deeper 
we decipher the molecular aspects of bacterial and viral pathogenesis, we find improved ways of eliminating them. ncRNAs could be candidates and become largely used in developing novel molecular diagnosis tools but, also, for crafting superior therapeutic options. ROS might actually be helpful with this process as well, due to their prooxidant properties that could be useful against different pathogenic infections.

Author Contributions: Conceptualization, I.B.-N. and M.L.; methodology, Z.M.; software, A.N.; validation, I.B.-N., P.C., and Z.M.; formal analysis, I.B.-N.; investigation, P.C.; resources, O.Z.; data curation, P.C.; writing-original draft preparation, P.C.; writing-review and editing, P.C. and O.Z.; visualization, M.I.; supervision, M.L.; project administration, I.B.-N.; and funding acquisition, I.B-N., Z.M. and P.C. contributed equally and should be considered as the primary co-authors. All authors have read and agreed to the published version of the manuscript.

Funding: This paper is part of the internal research grant 2461/45/17.01.2020 from Iuliu Hatieganu University of Medicine and Pharmacy, Cluj-Napoca, Romania.

Data Availability Statement: Not Applicable.

Conflicts of Interest: The authors declare no conflict of interest.

\section{References}

1. Kaufmann, S.H.E.; Dorhoi, A.; Hotchkiss, R.S.; Bartenschlager, R. Host-Directed Therapies for Bacterial and Viral Infections. Nat. Rev. Drug Discov. 2018, 17, 35-56. [CrossRef]

2. Smith, K.M.; Machalaba, C.C.; Seifman, R.; Feferholtz, Y.; Karesh, W.B. Infectious Disease and Economics: The Case for Considering Multi-Sectoral Impacts. One Health 2019, 7, 10080. [CrossRef] [PubMed]

3. Magill, S.S.; Edwards, J.R.; Bamberg, W.; Beldavs, Z.G.; Dumyati, G.; Kainer, M.A.; Lynfield, R.; Maloney, M.; McAllister-Hollod, L.; Nadle, J.; et al. Multistate Point-Prevalence Survey of Health Care-Associated Infections. N. Engl. J. Med. 2014, 370, 1198-1208. [CrossRef]

4. Zimlichman, E.; Henderson, D.; Tamir, O.; Franz, C.; Song, P.; Yamin, C.K.; Keohane, C.; Denham, C.R.; Bates, D.W. Health Care-Associated Infections: AMeta-Analysis of Costs and Financial Impact on the US Health Care System. JAMA Intern. Med. 2013, 173, 2039-2046. [CrossRef] [PubMed]

5. Riley, L.W.; Blanton, R.E. Advances in Molecular Epidemiology of Infectious Diseases: Definitions, Approaches, and Scope of the Field. Microbiol. Spectr. 2018, 6. [CrossRef]

6. Tobin, N.H.; Campbell, A.J.P.; Zerr, D.M.; Melvin, A.J. Life-Threatening Viral Diseases and Their Treatment. In Pediatric Critical Care; Elsevier Inc.: Amsterdam, The Netherlands, 2011; pp. 1324-1335.

7. Aliberti, S.; Kaye, K.S. The Changing Microbiologic Epidemiology of Community-Acquired Pneumonia. Postgrad. Med. 2013, 125, 31-42. [CrossRef]

8. Self, W.H.; Balk, R.A.; Grijalva, C.G.; Williams, D.J.; Zhu, Y.; Anderson, E.J.; Waterer, G.W.; Courtney, D.M.; Bramley, A.M.; Trabue, C.; et al. Procalcitonin as a Marker of Etiology in Adults Hospitalized with Community-Acquired Pneumonia. Clin. Infect. Dis. 2017, 65, 183-190. [CrossRef] [PubMed]

9. Cawcutt, K.; Kalil, A.C. Pneumonia with Bacterial and Viral Coinfection. Curr. Opin. Crit. Care 2017, 23, 385-390. [CrossRef]

10. Ruuskanen, O.; Järvinen, A. What Is the Real Role of Respiratory Viruses in Severe Community-Acquired Pneumonia? In Clinical Infectious Diseases; Oxford University Press: Oxford, UK, 2014; pp. 71-73.

11. Kang, Y.; Xu, S. Comprehensive Overview of COVID-19 Based on Current Evidence. Dermatol. Ther. 2020, 33, e13525. [CrossRef] [PubMed]

12. Fischer Walker, C.L.; Rudan, I.; Liu, L.; Nair, H.; Theodoratou, E.; Bhutta, Z.A.; O’Brien, K.L.; Campbell, H.; Black, R.E. Global Burden of Childhood Pneumonia and Diarrhoea. Lancet 2013, 381, 1405-1416. [CrossRef]

13. Qureshi, A.; Niazi, J.H. Biosensors for Detecting Viral and Bacterial Infections Using Host Biomarkers: A Review. Analyst 2020, 145, 7825-7848. [CrossRef]

14. Tsao, Y.-T.; Tsai, Y.-H.; Liao, W.-T.; Shen, C.-J.; Shen, C.-F.; Cheng, C.-M. Differential Markers of Bacterial and Viral Infections in Children for Point-of-Care Testing. Trends Mol. Med. 2020, 26, 1118-1132. [CrossRef]

15. Chang, Z.; Wang, Y.; Zhou, X.; Long, J.E. STAT3 Roles in Viral Infection: Antiviral or Proviral? Future Virol. 2018, 13, 557-574. [CrossRef]

16. Sampson, D.L.; Fox, B.A.; Yager, T.D.; Bhide, S.; Cermelli, S.; McHugh, L.C.; Seldon, T.A.; Brandon, R.A.; Sullivan, E.; Zimmerman, J.J.; et al. A Four-Biomarker Blood Signature Discriminates Systemic Inflammation Due to Viral Infection versus Other Etiologies. Sci. Rep. 2017, 7, 2914. [CrossRef]

17. Esteller, M. Non-Coding RNAs in Human Disease. Nat. Rev. Genet. 2011, 12, 861-874. [CrossRef]

18. Lekka, E.; Hall, J. Noncoding RNAs in Disease. FEBS Lett. 2018, 592, 2884-2900. [CrossRef] [PubMed]

19. Palazzo, A.F.; Lee, E.S. Non-Coding RNA: What Is Functional and What Is Junk? Front. Genet. 2015, 5, 2. [CrossRef]

20. Calin, G.A.; Dumitru, C.D.; Shimizu, M.; Bichi, R.; Zupo, S.; Noch, E.; Aldler, H.; Rattan, S.; Keating, M.; Rai, K.; et al. Frequent Deletions and Down-Regulation of Micro-RNA Genes MiR15 and MiR16 at 13q14 in Chronic Lymphocytic Leukemia. Proc. Natl. Acad. Sci. USA 2002, 99, 15524-15529. [CrossRef] [PubMed] 
21. Choudhuri, S. Small Noncoding RNAs: Biogenesis, Function, and Emerging Significance in Toxicology. J. Biochem. Mol. Toxicol. 2010, 24, 195-216. [CrossRef] [PubMed]

22. Vishnoi, A.; Rani, S. MiRNA Biogenesis and Regulation of Diseases: An Overview. In Methods in Molecular Biology; Humana Press Inc.: Totowa, NJ, USA, 2017; Volume 1509, pp. 1-10.

23. Hombach, S.; Kretz, M. Non-Coding RNAs: Classification, Biology and Functioning. Adv. Exp. Med. Biol. 2016, $937,3-17$.

24. Yang, B.; Chen, Y.; Shi, J. Reactive Oxygen Species (ROS)-Based Nanomedicine. Chem. Rev. 2019, 119, 4881-4985. [CrossRef]

25. Sun, J.; Wang, J.; Li, L.; Wu, Z.; Chen, X.; Yuan, J. ROS induced by spring viraemia of carp virus activate the inflammatory response via the MAPK/AP-1 and PI3K signaling pathways. Fish Shellfish Immunol. 2020, 101, 216-224. [CrossRef] [PubMed]

26. Ware, H.H.; Kulkarni, V.V.; Wang, Y.; Pantaleón García, J.; Leiva Juarez, M.; Kirkpatrick, C.T.; Wali, S.; Syed, S.; Kontoyiannis, A.D.; Sikkema, W.K.A.; et al. Inducible lung epithelial resistance requires multisource reactive oxygen species generation to protect against bacterial infections. PLoS ONE 2019, 14, e0208216. [CrossRef]

27. Treiber, T.; Treiber, N.; Meister, G. Regulation of MicroRNA Biogenesis and Its Crosstalk with Other Cellular Pathways. Nat. Rev. Mol. Cell Biol. 2019, 20, 5-20. [CrossRef] [PubMed]

28. O'Brien, J.; Hayder, H.; Zayed, Y.; Peng, C. Overview of MicroRNA Biogenesis, Mechanisms of Actions, and Circulation. Front. Endocrinol. 2018, 9, 402. [CrossRef]

29. Dahariya, S.; Paddibhatla, I.; Kumar, S.; Raghuwanshi, S.; Pallepati, A.; Gutti, R.K. Long Non-Coding RNA: Classification, Biogenesis and Functions in Blood Cells. Mol. Immunol. 2019, 112, 82-92. [CrossRef]

30. Quinn, J.J.; Chang, H.Y. Unique Features of Long Non-Coding RNA Biogenesis and Function. Nat. Rev. Genet. 2016, 17, 47-62. [CrossRef]

31. Statello, L.; Guo, C.J.; Chen, L.L.; Huarte, M. Gene Regulation by Long Non-Coding RNAs and Its Biological Functions. Nat. Rev. Mol. Cell Biol. 2021, 22, 96-118. [CrossRef] [PubMed]

32. Wen, Y.; Chen, H.; Luo, F.; Zhou, H.; Li, Z. Roles of Long Noncoding RNAs in Bacterial Infection. Life Sci. 2020, $263,118579$. [CrossRef] [PubMed]

33. Tang, B.; Li, N.; Gu, J.; Zhuang, Y.; Li, Q.; Wang, H.G.; Fang, Y.; Yu, B.; Zhang, J.Y.; Xie, Q.H.; et al. Compromised Autophagy by MIR30Bbenefits the Intracellular Survival of Helicobacter pylori. Autophagy 2012, 8, 1045-1057. [CrossRef]

34. Lind, E.F.; Elford, A.R.; Ohashi, P.S. Micro-RNA 155 Is Required for Optimal CD8 + T Cell Responses to Acute Viral and Intracellular Bacterial Challenges. J. Immunol. 2013, 190, 1210-1216. [CrossRef] [PubMed]

35. Ma, F.; Xu, S.; Liu, X.; Zhang, Q.; Xu, X.; Liu, M.; Hua, M.; Li, N.; Yao, H.; Cao, X. The MicroRNA MiR-29 Controls Innate and Adaptive Immune Responses to Intracellular Bacterial Infection by Targeting Interferon- $\gamma$. Nat. Immunol. 2011, 12, 861-869. [CrossRef]

36. Wang, Y.; Zhong, H.; Xie, X.; Chen, C.Y.; Huang, D.; Shen, L.; Zhang, H.; Chen, Z.W.; Zeng, G. Long Noncoding RNA Derived from CD244 Signaling Epigenetically Controls CD8+ T-Cell Immune Responses in Tuberculosis Infection. Proc. Natl. Acad. Sci. USA 2015, 112, E3883-E3892. [CrossRef] [PubMed]

37. Huang, S.; Huang, Z.; Luo, Q.; Qing, C. The Expression of LncRNA NEAT1 in Human Tuberculosis and Its Antituberculosis Effect. BioMed Res. Int. 2018, 2018, 9529072. [CrossRef] [PubMed]

38. Penkala, I.; Wang, J.; Syrett, C.M.; Goetzl, L.; López, C.B.; Anguera, M.C. LncRHOXF1, a Long Noncoding RNA from the X Chromosome That Suppresses Viral Response Genes during Development of the Early Human Placenta. Mol. Cell. Biol. 2016, 36, 1764-1775. [CrossRef]

39. Reshi, M.L.; Su, Y.C.; Hong, J.R. RNA Viruses: ROS-Mediated Cell Death. Int. J. Cell Biol. 2014, 2014, 467452. [CrossRef]

40. Paiva, C.N.; Bozza, M.T. Are reactive oxygen species always detrimental to pathogens? Antioxid. Redox Signal. 2014, $20,1000-1037$. [CrossRef]

41. Aryal, B.; Suárez, Y. Non-Coding RNA Regulation of Endothelial and Macrophage Functions during Atherosclerosis. Vasc. Pharmacol. 2019, 114, 64-75. [CrossRef] [PubMed]

42. Chan, J.J.; Tay, Y. Noncoding RNA: RNA Regulatory Networks in Cancer. Int. J. Mol. Sci. 2018, 19, 1310. [CrossRef]

43. Sharma, N.; Singh, S.K. Implications of Non-Coding RNAs in Viral Infections. Rev. Med. Virol. 2016, 26, 356-368. [CrossRef]

44. Duval, M.; Cossart, P.; Lebreton, A. Mammalian MicroRNAs and Long Noncoding RNAs in the Host-Bacterial Pathogen Crosstalk. Semin. Cell Dev. Biol. 2017, 65, 11-19. [CrossRef]

45. Peterson, S.M.; Thompson, J.A.; Ufkin, M.L.; Sathyanarayana, P.; Liaw, L.; Congdon, C.B. Common Features of MicroRNA Target Prediction Tools. Front. Genet. 2014, 5, 23. [CrossRef]

46. Taganov, K.D.; Boldin, M.P.; Chang, K.J.; Baltimore, D. NF-KB-Dependent Induction of MicroRNA MiR-146, an Inhibitor Targeted to Signaling Proteins of Innate Immune Responses. Proc. Natl. Acad. Sci. USA 2006, 103, 12481-12486. [CrossRef] [PubMed]

47. Jin, W.; Ibeagha-Awemu, E.M.; Liang, G.; Beaudoin, F.; Zhao, X.; Guan, L.L. Transcriptome MicroRNA Profiling of Bovine Mammary Epithelial Cells Challenged with Escherichia coli or Staphylococcus aureus Bacteria Reveals Pathogen Directed MicroRNA Expression Profiles. BMC Genom. 2014, 15, 181. [CrossRef]

48. Zeng, F.R.; Tang, L.J.; He, Y.; Garcia, R.C. An Update on the Role of MiRNA-155 in Pathogenic Microbial Infections. Microbes Infect. 2015, 17, 613-621. [CrossRef] [PubMed]

49. Maudet, C.; Mano, M.; Eulalio, A. MicroRNAs in the Interaction between Host and Bacterial Pathogens. FEBS Lett. 2014, 588, 4140-4147. [CrossRef] 
50. Josset, L.; Tisoncik-Go, J.; Katze, M.G. Noncoding RNA Expression during Viral Infection: The Long and the Short of It. In MicroRNAs and Other Non-Coding RNAs in Inflammation; Springer International Publishing: Cham, Switzerland, 2015 ; pp. 107-137.

51. Munschauer, M.; Vogel, J. Nuclear Lnc RNA Stabilization in the Host Response to Bacterial Infection. EMBO J. 2018, 37 , e99875. [CrossRef] [PubMed]

52. Zur Bruegge, J.; Einspanier, R.; Sharbati, S. A Long Journey Ahead: Long Non-Coding RNAs in Bacterial Infections. Front. Cell. Infect. Microbiol. 2017, 7, 95. [CrossRef] [PubMed]

53. Verma, S.; Mohapatra, G.; Ahmad, S.M.; Rana, S.; Jain, S.; Khalsa, J.K.; Srikanth, C.V. Salmonella Engages Host MicroRNAs To Modulate SUMOylation: A New Arsenal for Intracellular Survival. Mol. Cell. Biol. 2015, 35, 2932-2946. [CrossRef] [PubMed]

54. Rajaram, M.V.S.; Ni, B.; Morris, J.D.; Brooks, M.N.; Carlson, T.K.; Bakthavachalu, B.; Schoenberg, D.R.; Torrelles, J.B.; Schlesinger, L.S. Mycobacterium tuberculosis Lipomannan Blocks TNF Biosynthesis by Regulating Macrophage MAPK-Activated Protein Kinase 2 (MK2) and MicroRNA MiR-125b. Proc. Natl. Acad. Sci. USA 2011, 108, 17408-17413. [CrossRef] [PubMed]

55. Singh, Y.; Kaul, V.; Mehra, A.; Chatterjee, S.; Tousif, S.; Dwivedi, V.P.; Suar, M.; Van Kaer, L.; Bishai, W.R.; Das, G. Mycobacterium tuberculosis Controls MicroRNA-99b (MiR-99b) Expression in Infected Murine Dendritic Cells to Modulate Host Immunity. J. Biol. Chem. 2013, 288, 5056-5061. [CrossRef]

56. Kumar, R.; Halder, P.; Sahu, S.K.; Kumar, M.; Kumari, M.; Jana, K.; Ghosh, Z.; Sharma, P.; Kundu, M.; Basu, J. Identification of a Novel Role of ESAT-6-Dependent MiR-155 Induction during Infection of Macrophages with Mycobacterium tuberculosis. Cell. Microbiol. 2012, 14, 1620-1631. [CrossRef]

57. Kumar, M.; Sahu, S.K.; Kumar, R.; Subuddhi, A.; Maji, R.K.; Jana, K.; Gupta, P.; Raffetseder, J.; Lerm, M.; Ghosh, Z.; et al. MicroRNA Let-7 Modulates the Immune Response to Mycobacterium tuberculosis Infection via Control of A20, an Inhibitor of the NF-KB Pathway. Cell Host Microbe 2015, 17, 345-356. [CrossRef] [PubMed]

58. Clare, S.; John, V.; Walker, A.W.; Hill, J.L.; Abreu-Goodger, C.; Hale, C.; Goulding, D.; Lawley, T.D.; Mastroeni, P.; Frankel, G.; et al. Enhanced Susceptibility to Citrobacter rodentium Infection in MicroRNA-155-Deficient Mice. Infect. Immun. 2013, 81, 723-732. [CrossRef] [PubMed]

59. Ro, Y.T.; Jo, G.H.; Jung, S.A.; Lee, E.H.; Shin, J.; Lee, J.H. Salmonella-Induced MiR-155 Enhances Necroptotic Death in Macrophage Cells via Targeting RIP1/3. Mol. Med. Rep. 2018, 18, 5133-5140. [CrossRef]

60. Cremer, T.J.; Ravneberg, D.H.; Clay, C.D.; Piper-Hunter, M.G.; Marsh, C.B.; Elton, T.S.; Gunn, J.S.; Amer, A.; Kanneganti, T.D.; Schlesinger, L.S.; et al. MiR-155 Induction by F. Novicida but Not the Virulent F. Tularensis Results in SHIP down-Regulation and Enhanced pro-Inflammatory Cytokine Response. PLoS ONE 2009, 4, e8508. [CrossRef]

61. Li, M.; Wang, J.; Fang, Y.; Gong, S.; Li, M.; Wu, M.; Lai, X.; Zeng, G.; Wang, Y.; Yang, K.; et al. MicroRNA-146a Promotes Mycobacterial Survival in Macrophages through Suppressing Nitric Oxide Production. Sci. Rep. 2016, 6, 23351. [CrossRef]

62. Zhang, T.; Yu, J.; Zhang, Y.; Li, L.; Chen, Y.; Li, D.; Liu, F.; Zhang, C.Y.; Gu, H.; Zen, K. Salmonella enterica Serovar Enteritidis Modulates Intestinal Epithelial Mir-128 Levels to Decrease Macrophage Recruitment via Macrophage Colony-Stimulating Factor. J. Infect. Dis. 2014, 209, 2000-2011. [CrossRef]

63. Gomez, J.A.; Wapinski, O.L.; Yang, Y.W.; Bureau, J.F.; Gopinath, S.; Monack, D.M.; Chang, H.Y.; Brahic, M.; Kirkegaard, K. The NeST Long NcRNA Controls Microbial Susceptibility and Epigenetic Activation of the Interferon- $\gamma$ Locus. Cell 2013, 152, 743-754. [CrossRef] [PubMed]

64. Zhang, Q.; Chen, C.Y.; Yedavalli, V.S.R.K.; Jeang, K.T. NEAT1 Long Noncoding RNA and Paraspeckle Bodies Modulate HIV-1 Posttranscriptional Expression. mBio 2013, 4, e00596-12. [CrossRef] [PubMed]

65. Imamura, K.; Imamachi, N.; Akizuki, G.; Kumakura, M.; Kawaguchi, A.; Nagata, K.; Kato, A.; Kawaguchi, Y.; Sato, H.; Yoneda, M.; et al. Long Noncoding RNA NEAT1-Dependent SFPQ Relocation from Promoter Region to Paraspeckle Mediates IL8 Expression upon Immune Stimuli. Mol. Cell 2014, 53, 393-406. [CrossRef]

66. Laha, S.; Saha, C.; Dutta, S.; Basu, M.; Chatterjee, R.; Ghosh, S.; Bhattacharyya, N.P. In Silico Analysis of Altered Expression of Long Non-Coding RNA in SARS-CoV-2 Infected Cells and Their Possible Regulation by STAT1, STAT3 and Interferon Regulatory Factors. Heliyon 2021, 7, e06395. [CrossRef]

67. Li, C.; Hu, X.; Li, L.; Li, J.H. Differential MicroRNA Expression in the Peripheral Blood from Human Patients with COVID-19. J. Clin. Lab. Anal. 2020, 34, e23590. [CrossRef] [PubMed]

68. Wong, R.R.; Abd-Aziz, N.; Affendi, S.; Poh, C.L. Role of MicroRNAs in Antiviral Responses to Dengue Infection. J. Biomed. Sci. 2020, 27, 4. [CrossRef]

69. Castrillón-Betancur, J.C.; Urcuqui-Inchima, S. Overexpression of MiR-484 and MiR-744 in Vero Cells Alters Dengue Virus Replication. Memórias Inst. Oswaldo Cruz 2017, 112, 281-291. [CrossRef]

70. Castillo, J.A.; Castrillón, J.C.; Diosa-Toro, M.; Betancur, J.G.; St Laurent, G.; Smit, J.M.; Urcuqui-Inchima, S. Complex Interaction between Dengue Virus Replication and Expression of MiRNA-133a. BMC Infect. Dis. 2016, 16, 29. [CrossRef]

71. Kambara, H.; Niazi, F.; Kostadinova, L.; Moonka, D.K.; Siegel, C.T.; Post, A.B.; Carnero, E.; Barriocanal, M.; Fortes, P.; Anthony, D.D.; et al. Negative Regulation of the Interferon Response by an Interferon-Induced Long Non-Coding RNA. Nucleic Acids Res. 2014, 42, 10668-10681. [CrossRef] [PubMed]

72. Qian, X.; Xu, C.; Zhao, P.; Qi, Z. Long Non-Coding RNA GAS5 Inhibited Hepatitis C Virus Replication by Binding Viral NS3 Protein. Virology 2016, 492, 155-165. [CrossRef] [PubMed]

73. Li, Q.; Lowey, B.; Sodroski, C.; Krishnamurthy, S.; Alao, H.; Cha, H.; Chiu, S.; El-Diwany, R.; Ghany, M.G.; Liang, T.J. Cellular MicroRNA Networks Regulate Host Dependency of Hepatitis C Virus Infection. Nat. Commun. 2017, 8, 1789. [CrossRef] 
74. Girardi, E.; López, P.; Pfeffer, S. On the Importance of Host MicroRNAs during Viral Infection. Front. Genet. 2018, 9, 439. [CrossRef]

75. Zhang, J.; Li, X.; Hu, J.; Cao, P.; Yan, Q.; Zhang, S.; Dang, W.; Lu, J. Long Noncoding RNAs Involvement in Epstein-Barr Virus Infection and Tumorigenesis. Virol. J. 2020, 17, 51. [CrossRef] [PubMed]

76. Ho, B.C.; Yu, S.L.; Chen, J.J.W.; Chang, S.Y.; Yan, B.S.; Hong, Q.S.; Singh, S.; Kao, C.L.; Chen, H.Y.; Su, K.Y.; et al. EnterovirusInduced MiR-141 Contributes to Shutoff of Host Protein Translation by Targeting the Translation Initiation Factor EIF4E. Cell Host Microbe 2011, 9, 58-69. [CrossRef] [PubMed]

77. Ingle, H.; Kumar, S.; Raut, A.A.; Mishra, A.; Kulkarni, D.D.; Kameyama, T.; Takaoka, A.; Akira, S.; Kumar, H. The MicroRNA MiR-485 Targets Host and Influenza Virus Transcripts to Regulate Antiviral Immunity and Restrict Viral Replication. Sci. Signal. 2015, 8, ra126. [CrossRef] [PubMed]

78. Song, H.; Wang, Q.; Guo, Y.; Liu, S.; Song, R.; Gao, X.; Dai, L.; Li, B.; Zhang, D.; Cheng, J. Microarray Analysis of MicroRNA Expression in Peripheral Blood Mononuclear Cells of Critically Ill Patients with Influenza A (H1N1). BMC Infect. Dis. 2013, 13, 257. [CrossRef]

79. Nguyen, T.H.; Liu, X.; Su, Z.Z.; Hsu, A.C.Y.; Foster, P.S.; Yang, M. Potential Role of MicroRNAs in the Regulation of Antiviral Responses to Influenza Infection. Front. Immunol. 2018, 9, 1541. [CrossRef]

80. Peng, F.; He, J.; Loo, J.F.C.; Yao, J.; Shi, L.; Liu, C.; Zhao, C.; Xie, W.; Shao, Y.; Kong, S.K.; et al. Identification of MicroRNAs in Throat Swab as the Biomarkers for Diagnosis of Influenza. Int. J. Med. Sci. 2016, 13, 77-84. [CrossRef]

81. Makkoch, J.; Poomipak, W.; Saengchoowong, S.; Khongnomnan, K.; Praianantathavorn, K.; Jinato, T.; Poovorawan, Y.; Payungporn, S. Human MicroRNAs Profiling in Response to Influenza A Viruses (Subtypes PH1N1, H3N2, and H5N1). Exp. Biol. Med. 2016, 241, 409-420. [CrossRef]

82. Qu, D.; Sun, W.W.; Li, L.; Ma, L.; Sun, L.; Jin, X.; Li, T.; Hou, W.; Wang, J.H. Long Noncoding RNA MALAT1 Releases Epigenetic Silencing of HIV-1 Replication by Displacing the Polycomb Repressive Complex 2 from Binding to the LTR Promoter. Nucleic Acids Res. 2019, 47, 3013-3027. [CrossRef]

83. Ray, R.M.; Morris, K.V. Long Non-Coding RNAs Mechanisms of Action in HIV-1 Modulation and the Identification of Novel Therapeutic Targets. Non-Coding RNA 2020, 6, 12. [CrossRef]

84. Chen, L.; Chen, L.; Zuo, L.; Gao, Z.; Shi, Y.; Yuan, P.; Han, S.; Yin, J.; Peng, B.; He, X.; et al. Short Communication: Long Noncoding RNA Gas5 Inhibits HIV-1 Replication through Interaction with MiR-873. AIDS Res. Hum. Retrovir. 2018, 34, 544-549. [CrossRef]

85. Imam, H.; Bano, A.S.; Patel, P.; Holla, P.; Jameel, S. The LncRNA NRON Modulates HIV-1 Replication in a NFAT-Dependent Manner and Is Differentially Regulated by Early and Late Viral Proteins. Sci. Rep. 2015, 5, 8639. [CrossRef]

86. Chao, T.C.; Zhang, Q.; Li, Z.; Tiwari, S.K.; Qin, Y.; Yau, E.; Sanchez, A.; Singh, G.; Chang, K.; Kaul, M.; et al. The Long Noncoding RNA HEAL Regulates HIV-1 Replication through Epigenetic Regulation of the HIV-1 Promoter. mBio 2019, 10, e020616-19. [CrossRef] [PubMed]

87. Postler, T.S.; Pantry, S.N.; Desrosiers, R.C.; Ghosh, S. Identification and Characterization of a Long Non-Coding RNA up-Regulated during HIV-1 Infection. Virology 2017, 511, 30-39. [CrossRef] [PubMed]

88. Jeffers, L.K.; Duan, K.; Ellies, L.G.; Seaman, W.T.; Burger-Calderon, R.A.; Diatchenko, L.B.; Webster-Cyriaque, J. Correlation of Transcription of MALAT-1, a Novel Noncoding RNA, with Deregulated Expression of Tumor Suppressor P53 in Small DNA Tumor Virus Models. J. Cancer Ther. 2013, 4, 774-786. [CrossRef] [PubMed]

89. Bhattacharyya, S.; Vrati, S. The Malat1 Long Non-Coding RNA Is Upregulated by Signalling through the PERK Axis of Unfolded Protein Response during Flavivirus Infection. Sci. Rep. 2015, 5, 17794. [CrossRef]

90. Fang, H.; Shuang, D.; Yi, Z.; Sheng, H.; Liu, Y. Up-Regulated MicroRNA-155 Expression Is Associated with Poor Prognosis in Cervical Cancer Patients. Biomed. Pharmacother. 2016, 83, 64-69. [CrossRef]

91. Santos, J.M.O.; da Silva, S.P.; Costa, N.R.; Gil da Costa, R.M.; Medeiros, R. The Role of MicroRNAs in the Metastatic Process of High-Risk HPV-Induced Cancers. Cancers 2018, 10, 493. [CrossRef] [PubMed]

92. Yamamoto, N.; Kinoshita, T.; Nohata, N.; Itesako, T.; Yoshino, H.; Enokida, H.; Nakagawa, M.; Shozu, M.; Seki, N. Tumor Suppressive MicroRNA-218 Inhibits Cancer Cell Migration and Invasion by Targeting Focal Adhesion Pathways in Cervical Squamous Cell Carcinoma. Int. J. Oncol. 2013, 42, 1523-1532. [CrossRef]

93. Zhong, J.; Yuan, H.; Xu, X.; Kong, S. MicroRNA-195 Inhibits Cell Proliferation, Migration and Invasion by Targeting Defective in Cullin Neddylation 1 Domain Containing 1 in Cervical Cancer. Int. J. Mol. Med. 2018, 42, 779-788.

94. Wang, F.; Li, Y.; Zhou, J.; Xu, J.; Peng, C.; Ye, F.; Shen, Y.; Lu, W.; Wan, X.; Xie, X. MiR-375 Is down-Regulated in Squamous Cervical Cancer and Inhibits Cell Migration and Invasion via Targeting Transcription Factor SP1. Am. J. Pathol. 2011, 179, $2580-2588$. [CrossRef]

95. Au Yeung, C.L.; Tsang, T.Y.; Yau, P.L.; Kwok, T.T. Human Papillomavirus Type 16 E6 Induces Cervical Cancer Cell Migration through the P53/MicroRNA-23b/Urokinase-Type Plasminogen Activator Pathway. Oncogene 2011, 30, 2401-2410. [CrossRef]

96. Zhou, X.; Li, X.; Wu, M. MiRNAs Reshape Immunity and Inflammatory Responses in Bacterial Infection. Signal Transduct. Target. Ther. 2018, 3, 14. [CrossRef]

97. Reed, M.B.; Domenech, P.; Manca, C.; Su, H.; Barczak, A.K.; Kreiswirth, B.N.; Kaplan, G. A Glycolipid of Hypervirulent Tuberculosis Strains That Inhibits the Innate Immune Response. Nature 2004, 431, 84-87. [CrossRef] [PubMed]

98. Wu, K.; Zhu, C.; Yao, Y.; Wang, X.; Song, J.; Zhai, J. MicroRNA-155-Enhanced Autophagy in Human Gastric Epithelial Cell in Response to Helicobacter pylori. Saudi J. Gastroenterol. Assoc. 2016, 22, 30-36. [CrossRef] [PubMed] 
99. Xiao, B.; Liu, Z.; Li, B.S.; Tang, B.; Li, W.; Guo, G.; Shi, Y.; Wang, F.; Wu, Y.; Tong, W.D.; et al. Induction of MicroRNA-155 during Helicobacter pylori Infection and Its Negative Regulatory Role in the Inflammatory Response. J. Infect. Dis. 2009, 200, 916-925. [CrossRef] [PubMed]

100. Kawai, T.; Akira, S. Toll-like Receptors and Their Crosstalk with Other Innate Receptors in Infection and Immunity. Immunity 2011, 34, 637-650. [CrossRef]

101. Rau, C.S.; Wu, S.C.; Yang, J.C.S.; Lu, T.H.; Wu, Y.C.; Chen, Y.C.; Tzeng, S.L.; Wu, C.J.; Hsieh, C.H. Profiling the Circulating MiRNAs in Mice Exposed to Gram-Positive and Gram-Negative Bacteria by Illumina Small RNA Deep Sequencing. J. Biomed. Sci. 2015, 22, 1. [CrossRef]

102. Zhang, Y.; Fan, M.; Geng, G.; Liu, B.; Huang, Z.; Luo, H.; Zhou, J.; Guo, X.; Cai, W.; Zhang, H. A Novel HIV-1-Encoded MicroRNA Enhances Its Viral Replication by Targeting the TATA Box Region. Retrovirology 2014, 11, 23. [CrossRef]

103. Nukui, M.; Mori, Y.; Murphy, E.A. A Human Herpesvirus 6A-Encoded MicroRNA: Role in Viral Lytic Replication. J. Virol. 2015, 89, 2615-2627. [CrossRef]

104. Kincaid, R.P.; Sullivan, C.S. Virus-Encoded MicroRNAs: An Overview and a Look to the Future. PLoS Pathog. 2012,8 , e1003018. [CrossRef]

105. Jopling, C.L.; Yi, M.K.; Lancaster, A.M.; Lemon, S.M.; Sarnow, P. Molecular Biology: Modulation of Hepatitis C Virus RNA Abundance by a Liver-Specific MicroRNA. Science 2005, 309, 1577-1581. [CrossRef]

106. Wu, Q.; Wang, X.; Ding, S.W. Viral Suppressors of RNA-Based Viral Immunity: Host Targets. Cell Host Microbe 2010, 8, 12-15. [CrossRef] [PubMed]

107. McCaskill, J.; Praihirunkit, P.; Sharp, P.M.; Buck, A.H. RNA-Mediated Degradation of MicroRNAs: A Widespread Viral Strategy? RNA Biol. 2015, 12, 579-585. [CrossRef] [PubMed]

108. Fani, M.; Zandi, M.; Ebrahimi, S.; Soltani, S.; Abbasi, S. The Role of MiRNAs in COVID-19 Disease. Future Virol. 2021, 16, 301-306. [CrossRef]

109. Farr, R.; Cheng, A.; Kedzierska, K. Altered MicroRNA Expression in COVID-19 Patients Enables Identication of SARS-CoV-2 Infection. Res. Sq. 2021. [CrossRef]

110. Liu, W.; Ding, C. Roles of LncRNAs in Viral Infections. Front. Cell. Infect. Microbiol. 2017, 7, 205. [CrossRef] [PubMed]

111. Wang, P.; Xu, J.; Wang, Y.; Cao, X. An Interferon-Independent LncRNA Promotes Viral Replication by Modulating Cellular Metabolism. Science 2017, 358, 1051-1055. [CrossRef]

112. McAninch, D.; Roberts, C.T.; Bianco-Miotto, T. Mechanistic Insight into Long Noncoding RNAs and the Placenta. Int. J. Mol. Sci. 2017, 18, 1371. [CrossRef] [PubMed]

113. Hum, C.; Loiselle, J.; Ahmed, N.; Shaw, T.A.; Toudic, C.; Pezacki, J.P. MicroRNA Mimics or Inhibitors as Antiviral Therapeutic Approaches Against COVID-19. Drugs 2021, 81, 517-531. [CrossRef]

114. Morishita, A.; Oura, K.; Tadokoro, T.; Fujita, K.; Tani, J.; Masaki, T. MicroRNA Interference in Hepatic Host-Pathogen Interac tions. Int. J. Mol. Sci. 2021, 22, 3554. [CrossRef]

115. Staedel, C.; Darfeuille, F. MicroRNAs and bacterial infection. Cell. Microbiol. 2013, 15, 1496-1507. [CrossRef]

116. Ozata, D.M.; Gainetdinov, I.; Zoch, A.; O'Carroll, D.; Zamore, P.D. PIWI-interacting RNAs: Small RNAs with big functions. Nat. Rev. Genet. 2019, 20, 89-108. [CrossRef] [PubMed]

117. Firmino, N.; Martinez, V.D.; Rowbotham, D.A.; Enfield, K.; Bennewith, K.L.; Lam, W.L. HPV status is associated with altered PIWI-interacting RNA expression pattern in head and neck cancer. Oral Oncol. 2016, 55, 43-48. [CrossRef]

118. Zhang, X.; Liang, Z.; Zhang, Y.; Zhu, M.; Zhu, Y.; Li, S.; Zhao, W.; Hu, X.; Wang, J. Specific PIWI-interacting small noncoding RNA expression patterns in pulmonary tuberculosis patients. Epigenomics 2019, 11, 1779-1794. [CrossRef] [PubMed]

119. de Araujo, L.S.; Ribeiro-Alves, M.; Leal-Calvo, T.; Leung, J.; Durán, V.; Samir, M.; Talbot, S.; Tallam, A.; Mello, F.; Geffers, R.; et al Reprogramming of Small Noncoding RNA Populations in Peripheral Blood Reveals Host Biomarkers for Latent and Active Mycobacterium tuberculosis Infection. mBio 2019, 10, e01037-19. [CrossRef]

120. Yan, L.; Chen, Y.G. Circular RNAs in Immune Response and Viral Infection. Trends Biochem. Sci. 2020, 45, 1022-1034. [CrossRef] [PubMed]

121. Xie, H.; Sun, H.; Mu, R.; Li, S.; Li, Y.; Yang, C.; Xu, M.; Duan, X.; Chen, L. The role of circular RNAs in viral infection and related diseases. Virus Res. 2021, 291, 198205. [CrossRef] [PubMed]

122. Ojha, R.; Nandani, R.; Chatterjee, N.; Prajapati, V.K. Emerging Role of Circular RNAs as Potential Biomarkers for the Diagnosis of Human Diseases. Adv. Exp. Med. Biol. 2018, 1087, 141-157.

123. Nunes, A.; Ribeiro, D.R.; Marques, M.; Santos, M.; Ribeiro, D.; Soares, A.R. Emerging Roles of tRNAs in RNA Virus Infections. Trends Biochem. Sci. 2020, 45, 794-805. [CrossRef]

124. Circu, M.L.; Aw, T.Y. Reactive Oxygen Species, Cellular Redox Systems, and Apoptosis. Free Radic. Biol. Med. 2010, 48, 749-762. [CrossRef]

125. Forman, H.J.; Maiorino, M.; Ursini, F. Signaling Functions of Reactive Oxygen Species. Biochemistry 2010, 49, 835-842. [CrossRef]

126. Kowaltowski, A.J.; de Souza-Pinto, N.C.; Castilho, R.F.; Vercesi, A.E. Mitochondria and Reactive Oxygen Species. Free Radic. Biol. Med. 2009, 47, 333-343. [CrossRef]

127. Spooner, R.; Yilmaz, Ö. The Role of Reactive-Oxygen-Species in Microbial Persistence and Inflammation. Int. J. Mol. Sci. 2011, 12, 334-352. [CrossRef] 
128. Geng, J.; Sun, X.; Wang, P.; Zhang, S.; Wang, X.; Wu, H.; Hong, L.; Xie, C.; Li, X.; Zhao, H.; et al. Kinases Mst1 and Mst2 Positively Regulate Phagocytic Induction of Reactive Oxygen Species and Bactericidal Activity. Nat. Immunol. 2015, 16, 1142-1152. [CrossRef]

129. Dryden, M. Reactive Oxygen Therapy: A Novel Therapy in Soft Tissue Infection. Curr. Opin. Infect. Dis. 2017, 30, 143-149. [CrossRef] [PubMed]

130. Sato, Y.; Unno, Y.; Miyazaki, C.; Ubagai, T.; Ono, Y. Multidrug-Resistant Acinetobacter baumannii Resists Reactive Oxygen Species and Survives in Macrophages. Sci. Rep. 2019, 9, 17462. [CrossRef] [PubMed]

131. Silwal, P.; Kim, J.K.; Kim, Y.J.; Jo, E.K. Mitochondrial Reactive Oxygen Species: Double-Edged Weapon in Host Defense and Pathological Inflammation During Infection. Front. Immunol. 2020, 11, 1649. [CrossRef]

132. Nguyen, G.T.; Green, E.R.; Mecsas, J. Neutrophils to the ROScue: Mechanisms of NADPH Oxidase Activation and Bacterial Resistance. Front. Cell. Infect. Microbiol. 2017, 7, 373. [CrossRef]

133. Grimm, M.J.; Robert Vethanayagam, R.; Almyroudis, N.G.; Lewandowski, D.; Rall, N.; Blackwell, T.S.; Segal, B.H. Role of NADPH Oxidase in Host Defense against Aspergillosis. Med. Mycol. 2011, 49, S144-S149. [CrossRef] [PubMed]

134. Holland, S.M. Chronic Granulomatous Disease. Clin. Rev. Allergy Immunol. 2010, 38, 3-10. [CrossRef]

135. Pizzolla, A.; Hultqvist, M.; Nilson, B.; Grimm, M.J.; Eneljung, T.; Jonsson, I.-M.; Verdrengh, M.; Kelkka, T.; Gjertsson, I.; Segal, B.H.; et al. Reactive Oxygen Species Produced by the NADPH Oxidase 2 Complex in Monocytes Protect Mice from Bacterial Infections. J. Immunol. 2012, 188, 5003-5011. [CrossRef]

136. van den Berg, J.M.; van Koppen, E.; Åhlin, A.; Belohradsky, B.H.; Bernatowska, E.; Corbeel, L.; Espanñol, T.; Fischer, A.; Kurenko-Deptuch, M.; Mouy, R.; et al. Chronic Granulomatous Disease: The European Experience. PLoS ONE 2009, 4, e5234. [CrossRef] [PubMed]

137. Handa, O.; Naito, Y.; Yoshikawa, T. Helicobacter pylori: A ROS-Inducing Bacterial Species in the Stomach. Inflamm. Res. 2010, 59, 997-1003. [CrossRef] [PubMed]

138. Sander, W.J.; Fourie, C.; Sabiu, S.; O’Neill, F.H.; Pohl, C.H.; O’Neill, H.G. Reactive Oxygen Species as Potential Antiviral Targets. Rev. Med. Virol. 2021. [CrossRef]

139. Kirkpatrick, C.T.; Wang, Y.; Leiva Juarez, M.M.; Shivshankar, P.; Pantaleón García, J.; Plumer, A.K.; Kulkarni, V.V.; Ware, H.H.; Gulraiz, F.; Chavez Cavasos, M.A.; et al. Inducible Lung Epithelial Resistance Requires Multisource Reactive Oxygen Species Generation to Protect against Viral Infections. mBio 2018, 9, e00696-18. [CrossRef]

140. Lee, C. Therapeutic Modulation of Virus-Induced Oxidative Stress via the Nrf2-Dependent Antioxidative Pathway. Oxid. Med. Cell. Longev. 2018, 2018, 6208067. [CrossRef] [PubMed]

141. Qiang, W.; Kuang, X.; Liu, J.; Liu, N.; Scofield, V.L.; Reid, A.J.; Jiang, Y.; Stoica, G.; Lynn, W.S.; Wong, P.K.Y. Astrocytes Survive Chronic Infection and Cytopathic Effects of the Ts1 Mutant of the Retrovirus Moloney Murine Leukemia Virus by Upregulation of Antioxidant Defenses. J. Virol. 2006, 80, 3273-3284. [CrossRef] [PubMed]

142. Reddy, P.V.B.; Agudelo, M.; Atluri, V.S.R.; Nair, M.P. Inhibition of Nuclear Factor Erythroid 2-Related Factor 2 Exacerbates HIV-1 Gp120-Induced Oxidative and Inflammatory Response: Role in HIV Associated Neurocognitive Disorder. Neurochem. Res. 2012, 37, 1697-1706. [CrossRef]

143. Reddy, P.V.B.; Gandhi, N.; Samikkannu, T.; Saiyed, Z.; Agudelo, M.; Yndart, A.; Khatavkar, P.; Nair, M.P.N. HIV-1 Gp120 Induces Antioxidant Response Element-Mediated Expression in Primary Astrocytes: Role in HIV Associated Neurocognitive Disorder. Neurochem. Int. 2012, 61, 807-814. [CrossRef]

144. Mastrantonio, R.; Cervelli, M.; Pietropaoli, S.; Mariottini, P.; Colasanti, M.; Persichini, T. HIV-Tat Induces the Nrf2/ARE Pathway through NMDA Receptor-Elicited Spermine Oxidase Activation in Human Neuroblastoma Cells. PLoS ONE 2016, 11, e0149802. [CrossRef]

145. Zhang, H.S.; Wu, T.C.; Sang, W.W.; Ruan, Z. EGCG Inhibits Tat-Induced LTR Transactivation: Role of Nrf2, AKT, AMPK Signaling Pathway. Life Sci. 2012, 90, 747-754. [CrossRef]

146. Zhang, H.S.; Li, H.Y.; Zhou, Y.; Wu, M.R.; Zhou, H. Sen. Nrf2 Is Involved in Inhibiting Tat-Induced HIV-1 Long Terminal Repeat Transactivation. Free Radic. Biol. Med. 2009, 47, 261-268. [CrossRef]

147. Fan, X.; Staitieh, B.S.; Jensen, J.S.; Mould, K.J.; Greenberg, J.A.; Joshi, P.C.; Koval, M.; Guidot, D.M. Activating the Nrf2-Mediated Antioxidant Response Element Restores Barrier Function in the Alveolar Epithelium of HIV-1 Transgenic Rats. Am. J. Physiol. Lung Cell. Mol. Physiol. 2013, 305, L267-L277. [CrossRef] [PubMed]

148. Saito, T.; Ichimura, Y.; Taguchi, K.; Suzuki, T.; Mizushima, T.; Takagi, K.; Hirose, Y.; Nagahashi, M.; Iso, T.; Fukutomi, T.; et al. P62/Sqstm1 Promotes Malignancy of HCV-Positive Hepatocellular Carcinoma through Nrf2-Dependent Metabolic Reprogramming. Nat. Commun. 2016, 7, 12030. [CrossRef]

149. Kosmider, B.; Messier, E.M.; Janssen, W.J.; Nahreini, P.; Wang, J.; Hartshorn, K.L.; Mason, R.J. Nrf2 Protects Human Alveolar Epithelial Cells against Injury Induced by Influenza A Virus. Respir. Res. 2012, 13, 43. [CrossRef]

150. Hosakote, Y.M.; Jantzi, P.D.; Esham, D.L.; Spratt, H.; Kurosky, A.; Casola, A.; Garofalo, R.P. Viral-Mediated Inhibition of Antioxidant Enzymes Contributes to the Pathogenesis of Severe Respiratory Syncytial Virus Bronchiolitis. Am. J. Respir. Crit. Care Med. 2011, 183, 1550-1560. [CrossRef]

151. Schaedler, S.; Krause, J.; Himmelsbach, K.; Carvajal-Yepes, M.; Lieder, F.; Klingel, K.; Nassal, M.; Weiss, T.S.; Werner, S.; Hildt, E. Hepatitis B Virus Induces Expression of Antioxidant Response Element-Regulated Genes by Activation of Nrf2. J. Biol. Chem. 2010, 285, 41074-41086. [CrossRef] [PubMed] 
152. Schachtele, S.J.; Hu, S.; Lokensgard, J.R. Modulation of Experimental Herpes Encephalitis-Associated Neurotoxicity through Sulforaphane Treatment. PLoS ONE 2012, 7, e36216. [CrossRef]

153. Tilton, C.; Clippinger, A.J.; Maguire, T.; Alwine, J.C. Human Cytomegalovirus Induces Multiple Means To Combat Reactive Oxygen Species. J. Virol. 2011, 85, 12585-12593. [CrossRef]

154. Gjyshi, O.; Bottero, V.; Veettil, M.V.; Dutta, S.; Singh, V.V.; Chikoti, L.; Chandran, B. Kaposi's Sarcoma-Associated Herpesvirus Induces Nrf2 during De Novo Infection of Endothelial Cells to Create a Microenvironment Conducive to Infection. PLoS Pathog. 2014, 10, e1004460. [CrossRef] [PubMed]

155. Olagnier, D.; Peri, S.; Steel, C.; van Montfoort, N.; Chiang, C.; Beljanski, V.; Slifker, M.; He, Z.; Nichols, C.N.; Lin, R.; et al. Cellular Oxidative Stress Response Controls the Antiviral and Apoptotic Programs in Dengue Virus-Infected Dendritic Cells. PLoS Pathog. 2014, 10, e1004566. [CrossRef] [PubMed]

156. Lee, J.; Song, C.H. Effect of Reactive Oxygen Species on the Endoplasmic Reticulum and Mitochondria during Intracellular Pathogen Infection of Mammalian Cells. Antioxidants 2021, 10, 872. [CrossRef] [PubMed]

157. Herb, M.; Schramm, M. Functions of ROS in Macrophages and Antimicrobial Immunity. Antioxidants 2021, 10, 313. [CrossRef] [PubMed]

158. Fu, P.; Ramchandran, R.; Sudhadevi, T.; Kumar, P.; Krishnan, Y.; Liu, Y.; Zhao, Y.; Parinandi, N.L.; Harijith, A.; Sadoshima, J.; et al. NOX4 Mediates Pseudomonas aeruginosa-Induced Nuclear Reactive Oxygen Species Generation and Chromatin Remodeling in Lung Epithelium. Antioxidants 2021, 10, 477. [CrossRef] [PubMed]

159. Warnatsch, A.; Tsourouktsoglou, T.D.; Branzk, N.; Wang, Q.; Reincke, S.; Herbst, S.; Gutierrez, M.; Papayannopoulos, V. Reactive Oxygen Species Localization Programs Inflammation to Clear Microbes of Different Size. Immunity 2017, 46, 421-432. [CrossRef]

160. Garaude, J.; Acín-Pérez, R.; Martínez-Cano, S.; Enamorado, M.; Ugolini, M.; Nistal-Villán, E.; Hervás-Stubbs, S.; Pelegrín, P.; Sander, L.E.; Enríquez, J.A.; et al. Mitochondrial respiratory-chain adaptations in macrophages contribute to antibacterial host defense. Nat. Immunol. 2016, 17, 1037-1045. [CrossRef]

161. Jadhav, V.S.; Krause, K.H.; Singh, S.K. HIV-1 Tat C Modulates NOX2 and NOX4 Expressions through MiR-17 in a Human Microglial Cell Line. J. Neurochem. 2014, 131, 803-815. [CrossRef]

162. Zhang, J.; Thakuri, B.K.C.; Zhao, J.; Nguyen, L.N.; Nguyen, L.N.T.; Cao, D.; Dang, X.; Khanal, S.; Schank, M.; Lu, Z.; et al Long Noncoding RNA HOTAIRM1 Promotes Myeloid-Derived Suppressor Cell Expansion and Suppressive Functions through up-Regulating HOXA1 Expression during Latent HIV Infection. AIDS 2020, 34, 2211-2221. [CrossRef]

163. Wang, J.; Wu, M.; Wen, J.; Yang, K.; Li, M.; Zhan, X.; Feng, L.; Li, M.; Huang, X. MicroRNA-155 Induction by Mycobacterium bovis BCG Enhances ROS Production through Targeting SHIP1. Mol. Immunol. 2014, 62, 29-36. [CrossRef]

164. Singh, A.K.; Ghosh, M.; Kumar, V.; Aggarwal, S.; Patil, S.A. Interplay between MiRNAs and Mycobacterium tuberculosis: Diagnostic and Therapeutic Implications. Drug Discov. Today 2021, 26, 1245-1255. [CrossRef]

165. Zhang, X.; Wang, C.; Shan, S.; Liu, X.; Jiang, Z.; Ren, T. TLR4/ROS/MiRNA-21 Pathway Underlies Lipopolysaccharide Instructed Primary Tumor Outgrowth in Lung Cancer Patients. Oncotarget 2016, 7, 42172-42182. [CrossRef]

166. Liang, S.; Song, Z.; Wu, Y.; Gao, Y.; Gao, M.; Liu, F.; Wang, F.; Zhang, Y. MicroRNA-27b Modulates Inflammatory Response and Apoptosis during Mycobacterium tuberculosis Infection. J. Immunol. 2018, 200, 3506-3518. [CrossRef]

167. Huang, T.; Pu, Q.; Zhou, C.; Lin, P.; Gao, P.; Zhang, X.; Chu, Y.; Yue, B.; Wu, M. MicroRNA-302/367 Cluster Impacts Host Antimicrobial Defense via Regulation of Mitophagic Response Against Pseudomonas aeruginosa Infection. Front. Immunol. 2020, 11, 1. [CrossRef]

168. Strickertsson, J.A.B.; Rasmussen, L.J.; Friis-Hansen, L. Enterococcus Faecalis Infection and Reactive Oxygen Species DownRegulates the MiR-17-92 Cluster in Gastric Adenocarcinoma Cell Culture. Genes 2014, 5, 726-738. [CrossRef] [PubMed]

169. Li, Y.; Chan, E.Y.; Li, J.; Ni, C.; Peng, X.; Rosenzweig, E.; Tumpey, T.M.; Katze, M.G. MicroRNA Expression and Virulence in Pandemic Influenza Virus-Infected Mice. J. Virol. 2010, 84, 3023-3032. [CrossRef]

170. Kim, S.M.; Hur, D.Y.; Hong, S.W.; Kim, J.H. EBV-Encoded EBNA1 Regulates Cell Viability by Modulating MiR34a-NOX2-ROS Signaling in Gastric Cancer Cells. Biochem. Biophys. Res. Commun. 2017, 494, 550-555. [CrossRef] [PubMed]

171. Li, Z.Q.; Gu, X.Y.; Hu, J.X.; Ping, Y.; Li, H.; Yan, J.Y.; Li, J.; Sun, R.; Yu, Z.J.; Zhang, Y. Hepatitis C Virus Core Protein Impairs Metabolic Disorder of Liver Cell via HOTAIR-Sirt1 Signalling. Biosci. Rep. 2016, 36, e00336. [CrossRef] [PubMed]

172. Xu, Y.; Yu, J.; Ma, C.; Gong, Z.; Wu, X.; Deng, G. Impact of Knockdown LincRNA-Cox2 on Apoptosis of Macrophage Infected with Bacillus Calmette-Guérin. Mol. Immunol. 2021, 130, 85-95. [CrossRef]

173. Zuo, K.; Kong, L.; Xue, D.; Yang, Y.; Xie, L. The Expression and Role of LncRNA AX800134 in Hepatitis B Virus-Related Hepatocellular Carcinoma. Virus Genes 2018, 54, 475-483. [CrossRef]

174. Sahin, U.; Karikó, K.; Türeci, Ö. MRNA-Based Therapeutics-Developing a New Class of Drugs. Nat. Rev. Drug Discov. 2014, 13, 759-780. [CrossRef]

175. Zhong, Z.; Mc Cafferty, S.; Combes, F.; Huysmans, H.; De Temmerman, J.; Gitsels, A.; Vanrompay, D.; Portela Catani, J.; Sanders, N.N. MRNA Therapeutics Deliver a Hopeful Message. Nano Today 2018, 23, 16-39. [CrossRef]

176. Zhang, C.; Maruggi, G.; Shan, H.; Li, J. Advances in MRNA Vaccines for Infectious Diseases. Front. Immunol. 2019, 10, 594. [CrossRef] [PubMed]

177. Nadhan, R.; Patra, D.; Krishnan, N.; Rajan, A.; Gopala, S.; Ravi, D.; Srinivas, P. Perspectives on mechanistic implications of ROS inducers for targeting viral infections. Eur. J. Pharmacol. 2021, 890, 173621. [CrossRef] [PubMed] 